\title{
THE RELATIONSHIP BETWEEN CERTAIN MICROBIOLOGICAL AND SOME ARBUSCULAR MYCORRHIZAL PARAMETERS OF PLANTS PREVALENT AROUND AN ALUMINUM BAUXITE MINE DEPOSIT
}

\author{
ATMACA, E. ${ }^{*}$ - ÇETIN KARACA, U. \\ Soil Science and Plant Nutrition Department, Agriculture Faculty, Selcuk University, Campus, \\ Konya, Turkey \\ (phone: +90-332-223-2962; fax: +90-332-241-0108) \\ *Corresponding author \\ e-mail: emelatmaca2016@gmail.com; phone: +90-332-223-2962; fax: +90-332-241-0108
}

(Received 25 $5^{\text {th }}$ Mar 2019; accepted $4^{\text {th }}$ Jul 2019)

\begin{abstract}
The aim of our research was to study certain microorganisms living in the root areas of plants growing in stressed habitats such as mining sites. In the present study, the distributions of arbuscular mycorrhizal fungi (A.M.F.) spores in the root rhizospheres of certain plants (Onopordum acanthium, Festuca glauca, Euphorbia helioscopia L., Plantago lanceolata L., Salvia officinalis, Mentha pulegium L., Verbascum thapsus L. and Crocus sativus L.) that are prevalent around the Seydişehir Aluminum Plant Bauxite Deposit (SAPBD) were examined along with the infection rates of these spores in the plant roots, and the morphological definitions of these spores were presented. The highest values in the number of arbuscular mycorrhizal spores, arbuscular mycorrhizal infection rate, dehydrogenase, catalase, urease enzyme activities, the total number of bacteria, the vesicle and arbuscule rates, and also the DSE (dark septate endophyte) fungal structures were obtained from the plant Euphorbia helioscopia L., and the soils taken from its rhizosphere. The most prevalent spore species detected in the soils sampled from the Bauxite Mine sampling area were Glomus sp., Acaulospora sp. and Archaeospora sp. Fluctuations were observed in the arbuscular mycorrhizal infection rates of the roots depending on the species of the plants.

Keywords: mycorrhizal infection rate, spore number, mine area, morphological identification, Seydişehir
\end{abstract}

\section{Introduction}

Fungi play a central role in many microbiological and ecological processes, influencing soil fertility, decomposition, the cycling of minerals and organic matter, as well as plant health and nutrition (Finlay, 2008). Different symbiotic mycorrhizal associations between plants and fungi occur, almost ubiquitously, throughout a wide range of terrestrial ecosystems. Mycorrhizae are very common in disturbed areas, which indicates their positive role in establishing and building the plant community. There are several studies reporting the role of mycorrhizae in stressed habitats (Kumar et al., 2003). Furthermore, mycorrhizal associations are essential to the colonization of nutrient-deficient soil heaps left after mining

Soil contamination by heavy metals is an issue of major importance in industrialized areas. The detrimental effects of heavy metals on soil's biochemical and biological properties have been reported in the past and microbes are the pioneer of the living creation and play a vital role in mine restoration (Singh et al., 2011b; Li et al., 2012; Ma et al., 2016) High concentrations of metal in soil are toxic to bacteria and fungi, but the roots of most plants growing in polluted soils are colonized by A.M. fungi (Shetty et al., 1994a). This is an indication of the ability of A.M. fungi to develop tolerance to contaminants. Most studies aimed at evaluating the relationship between AMF and 
plants in soil contaminated with high metals have found increased tolerance and reduced damage in mycorrhizal plants (Shaker-Koohi, 2014). The species richness of $\mathrm{AMF}$ in mining areas has also been reported to be inversely related to soil high metal levels. The metals $\mathrm{Zn}, \mathrm{Cu}$, and $\mathrm{Pb}$ (Klauberg-Filho et al., 2002); $\mathrm{Pb}$ and $\mathrm{Zn}$ (Zarei et al., 2010); and Al, As, Ba, Cd, Cr, Cu, Pb, Se, Sr, and Zn (Biró et al., 2005) are some of the metals involved in reducing the diversity of mycobionts. However, despite the apparent exclusion of species and increased dominance imposed by the environmental damage generated by mining, AMF communities are rarely composed of less than 10 species. In areas of bauxite mining in Brazil, the number of species was found to vary from six (Melloni et al., 2003) to 21 (Silva et al., 2005).

When metals are at toxic concentrations in soil, mycorrhizal rather than nonmycorrhizal host plants are able to colonize these polluted sites (Shetty et al., 1994a, b). Thus, mycorrhizal colonization may be the key to plant survival in contaminated environments by enhancing metal resistance in plants and also by improving the uptake of essential nutrients. Nevertheless, metal resistance in A.M. fungi has not been extensively investigated with respect to their host plants (Meharg and Cairney, 2000). These studies demonstrate that plants are able to adapt quickly. Arbuscular mycorrhizal fungi, which are associated with most plant species and can serve as intermediaries for the uptake of soil nutrients, might be particularly important in mine tailings (Taheri and Bever, 2010). For example, Cumming and Ning (2003) found that A.M. fungi conferred $\mathrm{Al}$ resistance to Andropogon virginicus $\mathrm{L}$. reducing $\mathrm{Al}$ uptake and translocation in host plants. The response of plants to mycorrhizal colonization combined with toxic metal exposure varies depending on plant species, fungal community, biotic and abiotic conditions, concentration of toxins, and $\mathrm{pH}$. This suggests complex interactions involving many variables (Dietterich et al., 2017; Maynard et al., 2018).

Yet, few studies have examined plant response in terms of the adaptation of their symbionts, particularly in comparison to unadapted communities (Taheri and Bever, 2010). Furthermore, the impact of A.M. fungi community on soil quality is important in that it helps us to understand the function of the ecosystems. Relevant studies can provide important guidance for maintaining the balance of the soil-plant system and the development of sustainable agriculture (Huang et al., 2014). Mycorrhizal infection can increase the absorption of various mineral nutrients by the host plants (Smith et al., 2011; Wang et al., 2011), improve the host plant's water utilization efficiency under drought conditions (Augé, 2001; Huang et al., 2011; Tian et al., 2013), improve the host plant's resistance to salinity and heavy metals (Bothe et al., 2010; Garg and Kaur, 2013) and improve the host plant's resistance to disease. (Wehner et al., 2010; Meyer et al., 2013) Since one part of the morphological structure of A.M. fungi is located in the plant roots, and the other part in the soil, its infection will inevitably affect both the host plant and soil ecology. Studies on the distribution and infection rates of mycorrhizal spores in mining areas around the world and also studies to determine the types of spores are gaining more importance with each passing day. However, there are no studies on the mycorrhizae that exist in mining areas in Turkey. So, we determined the rate of mycorrhizal colonization in the plant root, the number of mycorrhizal spores in the plant rhizosphere and conducted the morphological identification of mycorrhizal spore species in various different plants growing in the vicinity of an aluminum mineral deposit. In doing so, we endeavored to make a general contribution to knowledge about the mycorrhizal state of these particular areas. 


\section{Materials and methods}

\section{Description of the sampling site}

This study was carried out in an opencast mine site at the Seydişehir Aluminum Plant Bauxite Deposit (SAPBD), in Konya, Turkey (N 1276 53, E 400727 and $1671 \mathrm{~m}$ ). This mining area is called the "Mortaş Bauxite Deposit". The Mortaş Bauxite Deposit is one of the largest bauxite deposits in the West Taurus Mountains and is located near Keçili village (the new name of the village is Madenli) located $15 \mathrm{~km}$ south of Seydişehir, and it occurs along the unconformity between Lower and Upper Cretaceous limestone layers (Atabey, 1976; Fig. 1).

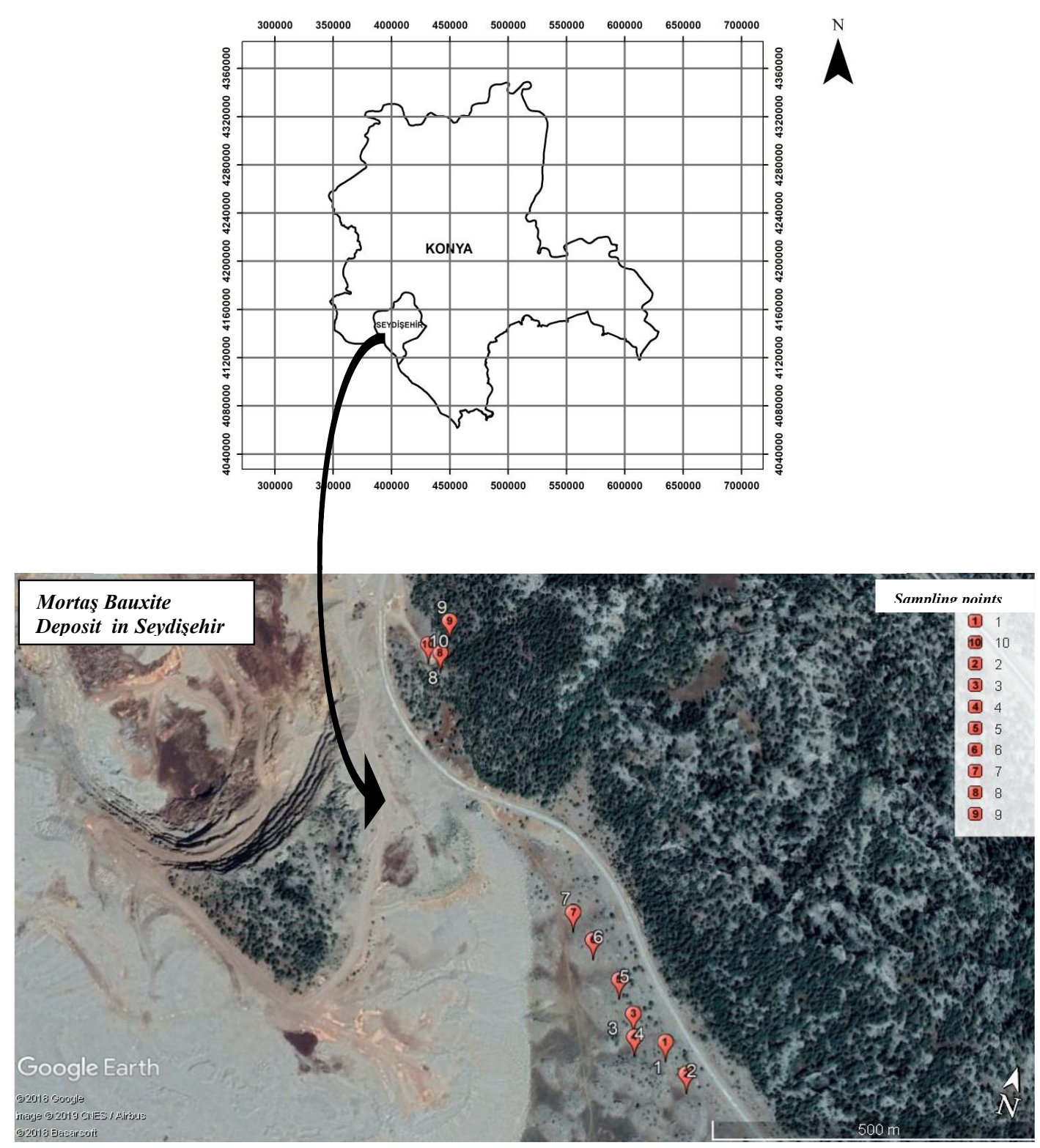

Figure 1. Research area (Seydişehir Mortaş Bauxite Deposit) and locations of sampling points

The Seydişehir-Akseki-Alanya district is of major economic importance and was investigated in the early 60's by A. Egger, who produced an unpublished detailed map 
of the regional geology of the area. The Seydişehir deposits contain a total of 26.3 million tons of high-alumina boehmite bauxite at 55-67\% $\mathrm{Al}_{2} \mathrm{O}_{3}$. Detailed exploration of the Seydisehir deposits by ETI Aluminum established a reserve of boehmitic bauxite measuring 25.8 million tons at 57-58\% $\mathrm{Al}_{2} \mathrm{O}_{3}, 6$ million tons of which have already been mined (Öztürk et al., 2002).

The mean meteorological data of Seydişehir District (where the sampling area is located) for the study period (January-December 2017) were obtained from the $8^{\text {th }}$ Konya Provincial Directorate of Meteorology. According to the data, the mean maximum temperature was $18.6^{\circ} \mathrm{C}$; the mean minimum temperature was $6.61{ }^{\circ} \mathrm{C}$; the average temperature was $12.60{ }^{\circ} \mathrm{C}$ and the temperature distribution was generally around the seasonal norms throughout the year. Total annual precipitation was 746.40 $\mathrm{mm}$ with $53.89 \%$ of this precipitation occurring in the winter season, and $20.72 \%$ in fall. The periods of summer and spring were arid. In the locality, annual average wind velocity is $1.5 \mathrm{~m} / \mathrm{s}$. Dominant wind direction is north- northwest and average velocity of the winds blowing from this direction is $1.2 \mathrm{~m} / \mathrm{s}$. The averaged soil temperature in the locality is $16.1^{\circ} \mathrm{C}$ in $5 \mathrm{~cm}$ depth; $15.8^{\circ} \mathrm{C}$ in $10 \mathrm{~cm}$ depth; $15.1^{\circ} \mathrm{C}$ in $20 \mathrm{~cm}$ depth; $15.6{ }^{\circ} \mathrm{C}$ in $50 \mathrm{~cm}$ depth; and $15.6{ }^{\circ} \mathrm{C}$ in $100 \mathrm{~cm}$ depth.

\section{Soil sampling and hosts}

Soil samples were taken through random sampling in autumn in 2017. The samples were taken from soil layers at 0 to $20 \mathrm{~cm}$ below the surface (where the plant roots are the most extensive and thus the activities of microorganisms are the highest) using a spade to collect about $1 \mathrm{~kg}$ of soil. A quantity of the sampled soils was kept at $+4{ }^{\circ} \mathrm{C}$ in a refrigerator so that microbiological analyses could be made. Later, the sampled soils were dried in air and passed through a $2 \mathrm{~mm}$ sieve in preparation for other analyses (some physical and some chemical). The number of soil samples was based on the number of the most prevalent perennial plants (The species were Asteraceae: Onopordum acanthium subsp. acanthium (1), Poaceae: Festuca glauca syn F. cinerea F. ovina var glauca (2), Euphorbiaceae: Euphorbia helioscopia L. (3 and 9: The same plant was sampled at a different distance to the pit), Plantaginaceae: Plantago lanceolata L. (4 and 8: The same plant was sampled at a different distance to the pit), Lamiaceae: Salvia officinalis L. and Mentha pulegium L. (5 and 6 respectively), Scrophulariaceae: Verbascum thapsus L. (7), Iridaceae: Crocus sativus L. (10). Samples of three of each of the aforementioned plants were taken from the sampling area, and the means of the values obtained from the three plants were used in the analyses. Plant names, localization and heights are presented in Table 1. The plants were described by Davis (1965-1985). In this study, the total number of plants is 10 , but there are 8 different plants in these 10. Three and eight are the same, and also four and nine are the same plant varieties and they are indicated as different sample numbers since those are sampled from different locations.

\section{Some microbiological, physical and chemical properties of the studied site soils}

The taken soil samples were air dried and passed through a $2 \mathrm{~mm}$ sieve before being analyzed in the laboratory. The analyses were conducted to determine soil characteristics, such as electrical conductivity (EC), $\mathrm{pH}, \mathrm{CaCO}_{3}$, organic matter, and texture. The electrical conductivity (EC) and $\mathrm{pH}$ of the samples were determined using an electrical meter and a $\mathrm{pH}$ meter, respectively (Richards, 1954). $\mathrm{CaCO}_{3}$ percentage 
was determined according to Hizalan and Ünal (1965); organic matter according to Jackson (1958); texture according to Bouyoucos (1995) by means of the hydrometer method. Total nitrogen was determined according to Bremner (1996) using the Kjeldahl method, and available phosphorus was determined by the Olsen method (Olsen et al., 1954). Ammonium acetate solution (1 N, pH 7) was used to determine exchangeable $\mathrm{Ca}, \mathrm{Mg}$ and $\mathrm{K}$ (Thomas, 1982). Available $\mathrm{Fe}, \mathrm{Cu}, \mathrm{Mn}$ and $\mathrm{Zn}$ were determined by atomic absorption spectrophotometry using DTPA extraction methods (Lindsay and Norwell, 1978). The sampled soils were subjected to microbiological analyses with their natural moisture content. The oven dry weights of the soils were determined and calculations were made according to the oven dry soil weight. Soil respiration was determined according to Isermeyer (1952); total bacteria and fungi count were determined according to the soil dilution and plate count method (Drews, 1983). The dehydrogenase activity (DHA) of the soils was determined according to Thalmann (1968); catalase activity (CA) was measured using the method by Beck (1971); urease activity was assayed using the method by Hoffmann and Teicher (1961). The percentage of root colonization was calculated by the gridline intersect method and, when the amount of roots was low by the slide method (Giovanetti and Mosse, 1980). The percentage of AM colonization was calculated as the number of segments infected out of 100 segments that were examined under a stereo microscope at $40 \mathrm{X}$ magnification (Giovanneti and Mosse, 1980). All the soil analyses and measurements were carried out in triplicate and the mean values were used in the statistical analysis.

Table 1. The plants sampled around SAPBD, and the coordinates and height above sea level of the locations from where they were taken

\begin{tabular}{c|c|c|c}
\hline No & Name of plant & Coordinate & Altitude (m) \\
\hline 1 & Onopordum acanthium (Asteraceae) & $37^{\circ} 16^{\prime} 15.76^{\prime \prime} \mathrm{N}, 31^{\circ} 53^{\prime} 50.61^{\prime \prime} \mathrm{E}$ & 1,611 \\
2 & Festuca glauca (Poaceae) & $37^{\circ} 16^{\prime} 14.37^{\prime \prime} \mathrm{N}, 31^{\circ} 53^{\prime} 52.53^{\prime \prime} \mathrm{E}$ & 1,611 \\
3 & Euphorbia helioscopia L. (Euphorbiaceae) & $37^{\circ} 16^{\prime} 16.80^{\prime \prime} \mathrm{N}, 31^{\circ} 53^{\prime} 48.03^{\prime \prime} \mathrm{E}$ & 1,607 \\
4 & Plantago lanceolata L. (Plantaginaceae) & $37^{\circ} 16^{\prime} 15.56^{\prime \prime} \mathrm{N}, 31^{\circ} 53^{\prime} 48.56^{\prime \prime} \mathrm{E}$ & 1,602 \\
5 & Salvia officinalis (Lamiaceae) & $37^{\circ} 16^{\prime} 18.45^{\prime \prime} \mathrm{N}, 31^{\circ} 53^{\prime} 46.46^{\prime \prime} \mathrm{E}$ & 1,607 \\
6 & Mentha pulegium L. (Lamiaceae) & $37^{\circ} 16^{\prime} 20.24^{\prime \prime} \mathrm{N}, 31^{\circ} 53^{\prime} 43.99^{\prime \prime} \mathrm{E}$ & 1,606 \\
7 & Verbascum thapsus L. (Scrophulariaceae) & $37^{\circ} 16^{\prime} 21.48^{\prime \prime} \mathrm{N}, 31^{\circ} 53^{\prime} 42.12^{\prime \prime} \mathrm{E}$ & 1,607 \\
8 & Plantago lanceolata L. (Plantaginaceae) & $37^{\circ} 16^{\prime} 33.63^{\prime \prime} \mathrm{N}, 31^{\circ} 53^{\prime} 28.22^{\prime \prime} \mathrm{E}$ & 1,689 \\
9 & Euphorbia helioscopia L. (Euphorbiaceae) & $37^{\circ} 16^{\prime} 35.52^{\prime \prime} \mathrm{N}, 31^{\circ} 53^{\prime} 28.18^{\prime \prime} \mathrm{E}$ & 1,698 \\
10 & Crocus sativus L. (Iridaceae) & $37^{\circ} 16^{\prime} 33.98^{\prime \prime} \mathrm{N}, 31^{\circ} 53^{\prime} 27.20^{\prime \prime} \mathrm{E}$ & 1,687 \\
\hline
\end{tabular}

\section{Assessment of arbuscular mycorrhizal fungi colonization and spores}

The root samples were cleaned carefully with deionized water and stained using the method described by Phillips and Hayman (1970), and the percentage colonization was calculated using the gridline intersect method (Giovanneti and Mosse, 1980).

The spores were quantified and characterized according to the sieving and decanting procedure developed by Gerdeman and Nicolson (1963) and INVAM (2004). Spore quantification was examined under a stereomicroscope (Olympus SX 60 trinocular microscope) at $40 \mathrm{X}$ magnification. For spore observation and identification, the spores 
were mounted on glass slides and identified to genus level, whenever possible, using a compound microscope (Euromex-Novex B-Series) at 100-400X magnification, based on the descriptions in Brundrett et al. (1996) and the information from the INVAM website (INVAM, 2004).

\section{Data analysis}

The data obtained were statistically analyzed using one-way analysis of variance and the means were separated by Duncan's multiple range test $(\mathrm{P}<0.01$ and 0.05$)$ using Minitab 16 software. Correlation analysis was also performed. Correlation coefficient $\left(r^{2}\right)$ was calculated between soil chemical features and mycorrhizal parameters (Minitab, 1997).

\section{Results and discussion}

\section{Physical and chemical properties of the site soil}

The means and standard deviations of some physical and chemical properties of the soil samples taken in three replicates from the rhizosphere soils of 10 plants (8 different plants) sampled around the SAPBD are given in Table 2.

Table 2. Results of some chemical analyses and textures belonging to the soils of plants sampled around SAPBD

\begin{tabular}{c|c|c|c|c|c}
\hline $\begin{array}{c}\text { Soil } \\
\text { number }\end{array}$ & $\mathbf{p H}$ & $\mathbf{E C} \boldsymbol{\mu S} / \mathbf{c m}$ & Org. mat. \% & $\mathbf{C a C O}_{\mathbf{3}} \%$ & Texture \\
\hline 1 & $7.23 \pm 0.01$ & $160.47 \pm 1.37$ & $2.31 \pm 0.04$ & $2.62 \pm 0.08$ & Loam \\
2 & $7.23 \pm 0.01$ & $299.33 \pm 1.96$ & $4.63 \pm 0.01$ & $4.36 \pm 0.00$ & Silty loam \\
3 & $6.50 \pm 0.26$ & $165.40 \pm 1.05$ & $5.27 \pm 0.04$ & $1.69 \pm 0.12$ & Loam \\
4 & $7.10 \pm 0.01$ & $140.83 \pm 0.65$ & $1.97 \pm 0.01$ & $2.68 \pm 0.04$ & Loam \\
5 & $7.36 \pm 0.04$ & $151.97 \pm 0.19$ & $2.26 \pm 0.07$ & $3.78 \pm 0.09$ & Loam \\
6 & $5.80 \pm 0.01$ & $145.77 \pm 0.54$ & $2.00 \pm 0.04$ & $6.05 \pm 0.12$ & Sandy loam \\
7 & $7.17 \pm 0.01$ & $128.23 \pm 0.49$ & $1.69 \pm 0.01$ & $6.63 \pm 0.08$ & Sandy loam \\
8 & $7.21 \pm 0.01$ & $113.73 \pm 1.04$ & $3.00 \pm 0.01$ & $50.68 \pm 1.53$ & Sandy clay loam \\
9 & $5.77 \pm 0.01$ & $134.74 \pm 1.29$ & $4.97 \pm 0.01$ & $40.38 \pm 0.99$ & Sandy loam \\
10 & $6.92 \pm 0.06$ & $131.26 \pm 1.13$ & $2.91 \pm 0.04$ & $26.47 \pm 1.19$ & Sandy clay loam \\
\hline
\end{tabular}

Regarding the soil characteristics of the survey area: $\mathrm{pH}$ varied between 5.77 and 7.36, organic matter content between 1.69 and $5.27 \%$, electrical conductivity between 113.73 and $299.33 \mathrm{dS} / \mathrm{cm}$, and percentage of $\mathrm{CaCO}_{3}$ between 1.69 and 50.68; texture classes were Loam, Silty Loam, Sandy Loam and Sandy Clay Loam (Table 2).

In addition, the contents of some micro and macro elements found in the soils sampled are presented in Table 3.

\section{Root colonization of A.M. fungi}

The roots of all 10 host plants were colonized by A.M. fungi, but the degree of colonization varied both among plant species and dependent on soil properties (Table 5). Typical A.M. fungal structures, i.e. arbuscules and vesicles (Fig. 2a-c, f) were 
observed in the roots of all host plants but moniliform cell and dark septate endophytic fungal hyphea (Fig. 2d-e) were observed only in the roots of Euphorbia helioscopia L. (Euphorbiaceae). The colonization of vesicles varied from $0.00 \%$ to $83.54 \%$, the colonization of arbuscules varied from $79.34 \%$ to $100 \%$, and the colonization of hyphae varied from $0.00 \%$ to $60.33 \%$. The highest vesicle and arbuscule rates were obtained from Euphorbia helioscopia L. (83.54\%-100\%), and the highest hyphae rate was obtained from Festuca glauca (60.33\%). Statistically significant differences were observed among the rhizospheres of different plant species $(\mathrm{P}<0.01$ and $\mathrm{P}<0.05)$ (Table 4). The mycorrhizal structures (arbuscules, vesicles and hypha) and also spore percentages were significantly higher (87.67 number/10 g soil) in the Euphorbia helioscopia L. compared to other plants and other rhizosphere soils.

Table 3. Results of some macro and micro nutrient elements belonging to the soils of plants sampled around SAPBD

\begin{tabular}{|c|c|c|c|c|c|c|c|c|c|}
\hline $\begin{array}{c}\text { Soil } \\
\text { number }\end{array}$ & $\begin{array}{l}\mathbf{N} \\
\%\end{array}$ & $\begin{array}{c}\mathrm{P}_{2} \mathrm{O}_{5} \\
\mathrm{mg} \mathrm{kg}^{-1}\end{array}$ & $\begin{array}{c}\mathrm{K}_{2} \mathrm{O} \\
\mathrm{mg} \mathrm{kg}^{-1}\end{array}$ & $\begin{array}{c}\mathrm{Ca} \\
\mathrm{mg} \mathrm{kg}^{-1}\end{array}$ & $\begin{array}{c}\mathrm{Mg} \\
\mathrm{mg} \mathrm{kg}^{-1}\end{array}$ & $\begin{array}{c}\mathrm{Fe} \\
\mathrm{mg} \mathrm{kg}^{-1}\end{array}$ & $\underset{\mathrm{mg} \mathrm{kg}^{-1}}{\mathrm{Cu}}$ & $\begin{array}{c}\mathrm{Zn} \\
\mathrm{mg} \mathrm{kg}^{-1}\end{array}$ & $\begin{array}{c}\mathrm{Mn} \\
\mathrm{mg} \mathrm{kg}^{-1}\end{array}$ \\
\hline 1 & 0.19712 & 13.78 & 198.3 & 6411 & 2050 & 24.52 & 1.336 & 0.388 & 21.81 \\
\hline 2 & 0.19222 & 34.59 & 273.7 & 7127 & 3070 & 33.41 & 1.512 & 0.838 & 35.61 \\
\hline 3 & 0.31892 & 34.59 & 368.7 & 5313 & 3790 & 32.01 & 1.87 & 0.792 & 22.95 \\
\hline 4 & 0.26012 & 17.29 & 220.9 & 5981 & 2800 & 23 & 1.294 & 0.412 & 305 \\
\hline 5 & 0.07056 & 16.41 & 239.3 & 6236 & 1980 & 20.39 & 1.026 & 0.332 & 21.46 \\
\hline 6 & 0.15022 & 13.48 & 150.3 & 6102 & 2540 & 28.18 & 1.114 & 0.292 & 20.7 \\
\hline 7 & 0.04536 & 10.26 & 147.7 & 6157 & 2640 & 23.32 & 0.958 & 0.252 & 15.88 \\
\hline 8 & 0.04368 & 9.38 & 83.86 & 3848 & 450 & 11.87 & 1.26 & 1.97 & 14.01 \\
\hline 9 & 0.09744 & 16.71 & 170.4 & 4374 & 620 & 27.58 & 0.95 & 0.546 & 16.21 \\
\hline 10 & 0.0504 & 15.53 & 192.2 & 4511 & 510 & 9.03 & 0.738 & 1.178 & 8.37 \\
\hline
\end{tabular}

Among the mycorrhizal parameters examined in plant roots, a positive correlation was found between vesicle rate and arbuscule rate at a significant level $(\mathrm{P}<0.01$, $r=0.6447)$, and a significant and positive correlation $(\mathrm{P}<0.05, \mathrm{r}=0.5009)$ was also found between vesicle rate and dehydrogenase activity. In addition to the positive and significant relationship between arbuscule rate and vesicle rate $(\mathrm{P}<0.01)$, a positive and significant relationship was again detected between arbuscule rate and the number of spores per screen opening 50-100 $\mu \mathrm{m}$ in diameter $(\mathrm{P}<0.01, \mathrm{r}=0.6306)$, and there was also a positive and significant relationship between arbuscule rate and urease enzyme activity $(\mathrm{P}<0.01, \mathrm{r}=0.3932)$. By contrast, a negative and significant correlation was detected between arbuscule rate and hyphae rate and between arbuscule rate and root length $(\mathrm{P}<0.05, \mathrm{r}=-0.3784$ and $\mathrm{r}=-0.5362$, respectively in Table 5).

The photographs of the different formations exhibited by arbuscular mycorrhizal and DSE fungal colonization observed in plant roots are shown in Figure $2 a-f$.

Of the mycorrhizal structures, the vesicle and arbuscule formations are shown in Figure $2 a, c$ and $f$, coiled intraradical hyphae (large arrow) are shown in Figure $2 b$, moniliform cells are shown in Figure $2 d$. Mycelia of dark septate endophytes (DSE) accompanied the A.M. fungi colonization, and were observed in only one plant species (Zubek et al., 2011). Dark septate endophytic fungal hyphea are shown in Figure 2e. All of these formations were obtained from the roots of the plant Euphorbia helioscopia L. 


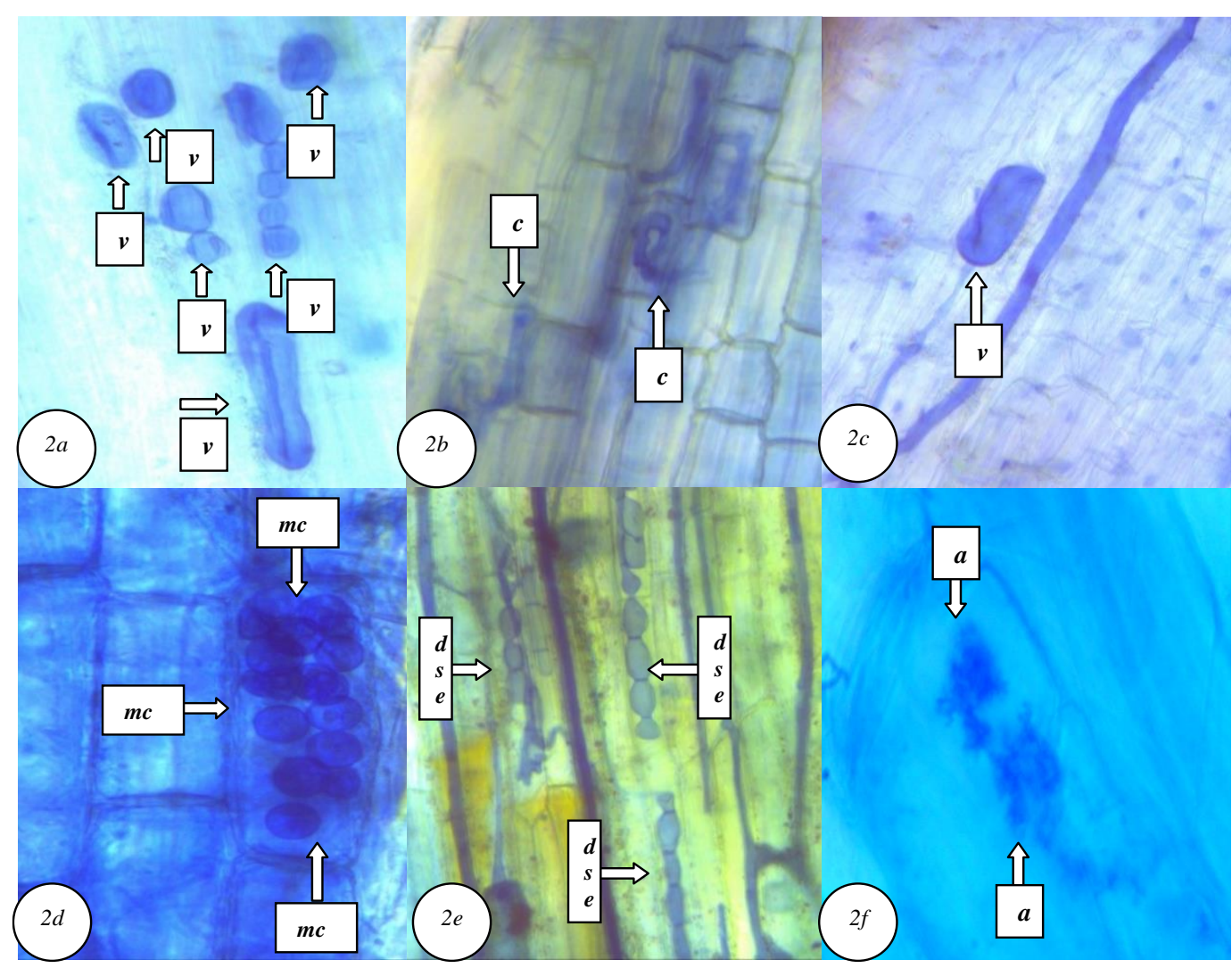

Figure 2. a Vesicles (v) in roots of Festuca glauca (Poaceae). $\boldsymbol{b}$ Stained coiled (c) intraradical hyphae (large arrow) in Salvia officinalis (Lamiaceae) roots. $c$ Vesicles (v) in roots of Plantago lanceolata L. (Plantaginaceae).d Moniliform cells $(\mathrm{mc})$ in Euphorbia helioscopia L.

(Euphorbiaceae). e Dark septate endophytic (dse) fungal hyphea in Euphorbia helioscopia L. (Euphorbiaceae) roots. $f$ Arbuscules (a) in roots of Euphorbia helioscopia L. (Euphorbiaceae)

\section{Spore density of A.M. fungi}

The total A.M. fungi spore density ranged between $24.33-87.67 \mathrm{count} / 10 \mathrm{~g}$ soil in the rhizosphere zone of the ten host plants. The highest A.M. fungi spore density was observed in the rhizosphere of the plant Euphorbia helioscopia L., and the lowest A.M. fungi spore density (24.33-26.00-26.00 count/10 g soil) was obtained in the rhizosphere of Verbascum thapsus L. and Plantago lanceolata L. (Two plants sampled). On the other hand, the distribution of spore numbers varied according to sieve size and plant variety. The highest spore counts were taken from smaller size $(38-50 \mu \mathrm{m})$ while the lowest spore counts were taken from larger size $(>250 \mu \mathrm{m})$ sieves.

Considering all sieve sizes, the highest spore count in the $38-50 \mu \mathrm{m}$ sieve was found at the rhizosphere region of Onorpodum acanthium (46.67 number/10 g soil), the highest spore count in the 50-100 and 100-250 $\mu \mathrm{m}$ sieves was found at the rhizosphere region of Euphoria helioscopia L. (39.00-32.00 number/10 g soil) and the highest spore count in the $>250 \mu \mathrm{m}$ sieve $(6.67$ number/10 g soil) was found at the rhizosphere region of Mentha pulegium L. (Table 4).

As can also be seen from Table 5, the correlation analysis carried out in the study revealed that there was a positive and significant relationship between the total number of spores and the number of spores remaining in the 30-50 $\mu \mathrm{m}$ sieve, and also between the total number of spores and the microbial respiration value and the total number of 
bacteria $(\mathrm{P}<0.01, \mathrm{r}=0.6969, \mathrm{r}=0.7609, \mathrm{r}=0.7404$, respectively). Similarly, a positive and significant relationship was again found $(\mathrm{P}<0.01)$ between the total number of spores and the number of spores remaining in the $100-150 \mu \mathrm{m}$ sieve, and between catalase urease enzyme activities and the total number of fungi $(r=0.4558, r=0.5233$, $\mathrm{r}=0.4169, \mathrm{r}=0.5425$, respectively) (Table 5).

\section{Evaluation of certain biological properties of the research area soil}

Certain mycorrhizal parameters, as well as microbiological properties of the research soils, were analyzed. In this scope, the dehydrogenase, catalase and urease activities of the soils, total number of fungus, bacteria, and microbial respiration values were determined. Of the parameters mentioned above, the highest values in terms of dehydrogenase, urease and catalase activities, vesicle-arbuscule rates, and the total number of mycorrhizal spores were obtained from the root rhizosphere of the plant Euphorbia helioscopia L. In addition, as the result of the distribution of the total number of mycorrhizal spores with respect to sieve diameter, the highest number of spores remaining on the $50-100 \mu \mathrm{m}$ and 100-250 $\mu \mathrm{m}$ sieves were also obtained from the rhizosphere of the same plant. Also, DSE fungal structures were determined from the root rhizosphere of the plant Euphorbia helioscopia L. Of the interpretations regarding the significance levels and degrees of the bilateral relationships between the analyzed biological parameters, those that are related to mycorrhizal parameters were presented above. The correlation analyses conducted on the root length data showed that there was a significant $(\mathrm{P}=0.05)$ and positive $(0.4911)$ relationship between root length and hypha rate; a significant $(\mathrm{P}=0.05)$ and negative $(-$ 0.5362) relationship between root length and arbuscule rate; also, a significant $(\mathrm{P}=0.01)$ and negative relationship between root length and the number of spores remaining on the $50-100 \mu \mathrm{m}$ sieve. While a significant $(\mathrm{P}<0.05)$ and positive $(0.4203)$ correlation was determined between dehydrogenase enzyme activity and urease enzyme activity, again a positive $(r=0.4963)$ correlation was found at the same level $(P<0.05)$ between dehydrogenase activity and total number of bacteria. It was determined that there was a positive correlation $(\mathrm{P}<0.01)$ between catalase enzyme activity and microbial respiration, and the number of spores remaining on the $35-50 \mu \mathrm{m}$ sieve $(r=0.7995$, $\mathrm{r}=0.7047$, respectively); also a positive correlation $(\mathrm{P}<0.05)$ was found between catalase enzyme activity and the number of spores remaining on the $50-100 \mu \mathrm{m}$ sieve, and hypha rate $(r=0.4092, r=0.4313$ respectively). From another enzyme analysis carried out in the soil, it was determined that there was a significant and positive correlation $(\mathrm{P}<0.05)$ between urease enzyme activity and number of spores remaining on the 50-100 $\mu \mathrm{m}$ sieve, dehydrogenase enzyme activity, and total number of bacteria $(\mathrm{r}=0.5339$, $\mathrm{r}=0.4203, \mathrm{r}=0.5497$, respectively) (Table 5).

\section{Determination of morphological diagnosis of A.M. fungi}

Morphological identifications were made for A.M. fungi spores that were isolated from the rhizosphere zones of the plants sampled from mining areas. The A.M. fungal spores counted in the study were found to belong to three different mycorrhizal fungi genera and the counting results were compared to one another. The plants that were in symbiosis with Acaulospora, Glomus and Scutellospora were found as Onopordum acanthium, Euphorbia helioscopia L., Plantago lanceolata L., and Crocus sativus L.. The highest number of mycorrhizal spores was detected in Glomus sp. The present study recorded a total of three A.M. fungal genera: Glomus sp. (Fig. 3a, 3i), 
Acaulospora sp. (Fig. 3b, 3d, 3e, 3h) and Entrophospora sp. (Fig. 3c, 3f, 3g). Acaulospora sp. was the most frequently occurring genera $(66.67 \%)$ followed by Glomus (22.22\%) and Entrophospora sp. (11.11\%).

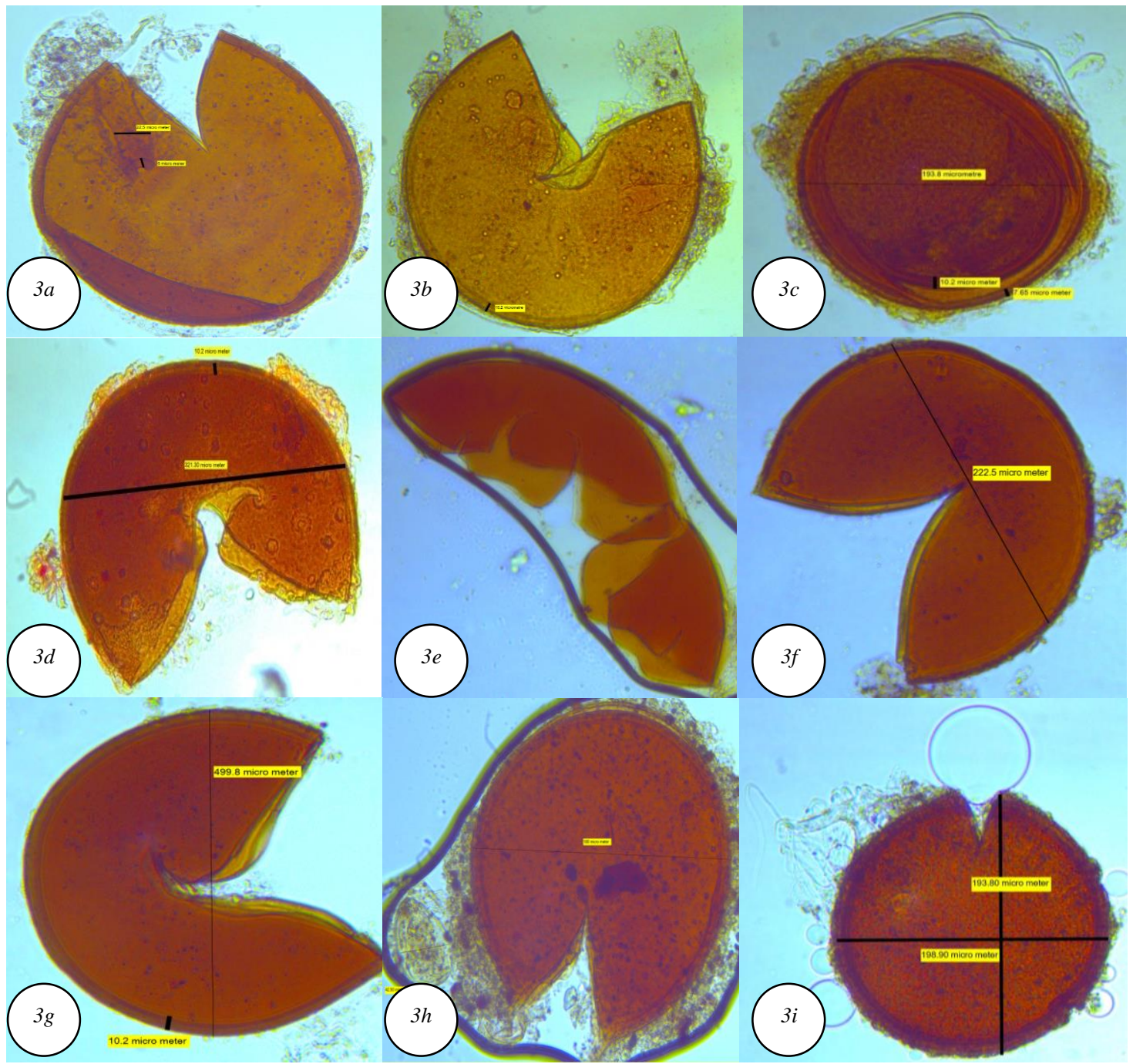

Figure 3. Three genus of mycorrhiza spores identified in plant rhizospheres. a X400 in PVLG;

$5-22.5 \mu \mathrm{m} . \boldsymbol{b}$ X200 in PVLG; $10.2 \mu \mathrm{m} . \boldsymbol{c} X 200$ in PVLG; 193.8 in Onopordum acanthium

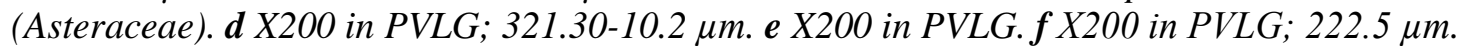
$\boldsymbol{g}$ X200 in PVLG; 499.8-10.2 $\mu \mathrm{m}$ in Plantago lanceolata L. (Plantaginaceae). $\boldsymbol{h}$ X400 in PVLG; 180-42.5 $\mu \mathrm{m}$ in Euphorbia helioscopia L. (Euphorbiaceae). $\boldsymbol{i}$ X200 in PVLG; 198.90-193.80 $\mu \mathrm{m}$

\section{Discussion} in Crocus sativus L. (Iridaceae)

From all of the findings, it can be said that both the distributions of mycorrhizal spores in the soil and the infection rates they formed in the plant roots may vary in the same plant and soil even in short term intervals. For this reason, the data obtained from microbiological studies in which mycorrhizal distribution and infection rates are determined can only represent the moment of collection and are valid for only a short period of time. Since microbiological parameters can be affected by various factors and the action mechanism is again a living organism system, the cycle of effective factors is both quick and fluctuated. 
In addition, although the distances among the locations where the mining area plants used in our study were sampled were not very far, differences were still observed in the mycorrhizal parameters measured in the soils and the plants, and also in the results of the analyses of the activities of other microorganisms, and these differences were found to be statistically significant $(\mathrm{P}<0.05)$, which confirms the statements explained above. As a matter of fact, the distribution of A.M. fungi in different ecological regions and their relations with soil properties and native plants have been investigated by several researchers (Cooke et al., 1993; Janardhanan, 1994; Aliasgharzadeh et al., 2001; Shi et al., 2007; Bi et al., 2019).

It is established that variations in A.M. fungi distribution, spore density and colonization with different host plant species are generated by a variety of mechanisms, including variation in host species and their phenology, mycorrhizal dependency, soil properties, host plant-mediated alteration of the soil microenvironment, or other unknown host plant traits (Eom et al., 2000; Wang et al., 2004). In addition, species and isolates of A.M. fungi differ in their tolerance to adverse physical and chemical conditions in soil (Augé, 2004; Daei et al., 2009; Barea et al., 2013). In our study, the highest values in terms of both mycorrhizal and other microbiological parameters were obtained particularly from the plant Euphorbia helioscopia L. This finding could be explained by the fact that this plant has a different physiology and thus a different mechanism compared to the others. Early reports revealed that plants of Euphorbiaceae contain many kinds of secondary metabolites, such as triterpenoids (Biesboer et al., 1982; Teresa et al., 1987), diterpenoids (Sahai et al., 1981; Yamamura et al., 1989; Öksüz et al., 1995; Madureira et al., 2004) steroids (Biesboer et al., 1982), lipids (Biesboer et al., 1982; Teresa et al., 1987), flavonoids and tannins (Durrani et al., 1987; Zhang and Guo, 2006). In addition to various medical and known properties of the plant, researchers conducted and have been continuing to carry out several studies on the use of the plant in agriculture and on its insecticide properties (Uzair et al., 2009). However, there are no studies on the potential of arbuscular mycorrhizal organisms that have a mutualistic symbiotic association with the root of Euphorbia helioscopia L. in the soil and their effects on the infection of mycorrhizal fungus spores in the plant root. For this reason, the data obtained in the present study could serve as a base for the future studies on similar topics.

In terms of the parameters examined in the study; although the values obtained from Euphorbia helioscopia L. were found to be higher compared to other plants, mycorrhizal fungus spores were observed in the root rhizospheres of all the plants examined in the study.

The spore numbers in the rhizosphere soil ranged between 24.33-87.67 spores per $10 \mathrm{~g}^{-1}$ dry soil. The average spore count recorded was 53.99 spores per $10 \mathrm{~g}^{-1}$ dry soil (Table 4).

In terms of the parameters examined in the study, although the values obtained from Euphorbia helioscopia L. were found to be higher compared to other plants, mycorrhizal fungus spores were observed in the root rhizospheres of all the plants examined in the study.

In the same way, arbuscule, vesicle, and hypha formations, which are among mycorrhizal parameters, were detected in the roots of all the plants. The A.M. fungi infection rate ranged between $0-83.54 \%$ (vesicle rate), $79.34-100 \%$ (arbuscule rate) and $0-60.33 \%$ (hypha rate) and the mean A.M. fungi infection rates recorded were 44.61$88.33-26.60 \%$ as vesicle, arbuscule and hypha rates, respectively. 
In addition, as can be seen from the correlation values in Table 5, there is a very strict and positive interaction between the mycorrhizal spore distribution in the soil and the other microbiological parameters of the soil analyzed in the study. The effect of soil enzymes is particularly noticeable in this interaction. Soil enzyme activity has been widely used to evaluate soil management effects (Dick, 1994; Bandick and Dick, 1999; Utobo and Tewari, 2014). The application of microorganism quantity and soil enzyme activity when investigating the effects of mycorrhizal fungi on soil ecosystem functions can improve our understanding of the correlation between mycorrhizal fungi and soil ecosystem functions. Many studies have shown that mycorrhizal colonization may affect the soil microbial communities either directly or indirectly through root exudates (Nuccio et al., 2013; Zubek et al., 2013). Camprubi et al. (1995), Kieliszewska-Rokicka (2001); Nadgórska-Socha et al. (2006); Fernández et al. (2012) investigated the effects of mycorrhizal fungi on soil biological quality by observing soil enzyme activity. In this paper, vesicle, arbuscule, and hypha rates also showed a relationship particularly with soil enzymes in addition to other microbiological parameters. The interactions of vesicle, arbuscule, and hypha rates with the enzymes in the soil were found to be different from one another. That is, a positive and significant correlation $(\mathrm{P}<0.01)$ was found between the vesicle rate determined in the plant roots and dehydrogenase enzyme activity, between arbuscule rate and urease enzyme activity, and between hypha rate and catalase enzyme activity. This interaction of mycorrhizal formations in the plant root with the presence of enzymes outside the root could be attributed to the fact that the enzymes mentioned have an effect on the existence of organic matter in the soil.

As a matter of fact, the finding that among the nine plants used in the study, the highest results for certain biological analyses were generally obtained from the root rhizosphere of the same plant could be explained by the fact that the plant has a specific structure and also that the soil in which it grows has a high content of organic matter, with this organic matter being a source of substrate for the enzymes mentioned above. Thus, urease is an extracellular enzyme that provides the hydrolysis of urea reaching the soil in various ways (plant residuals, animal tissues, and fertilizers). After these enzymes are produced by the soil microorganisms to decompose the nutrient substances, they are kept by colloids of soils such as clay and organic matter and can sustain their activities independent of the microorganism cell producing these enzymes. The distribution of urease activity in the soils in the study area is shown in Table 4. In the soils studied, the values of urease activity were obtained between 8.71-77.87 $\mu \mathrm{g}$ per $\mathrm{N} \mathrm{g}$ dry soil ${ }^{-1}$ and it was seen that the highest activity occurred in the soil taken from the rhizosphere of the plant Euphorbia helioscopia L. (Euphorbiaceae) (no.9), which had the lowest $\mathrm{pH}$ (5.77), while the lowest activity was observed in the soil taken from the rhizosphere of the plant Verbascum thapsus L. (Scrophulariaceae). Similar values of urease activity were also obtained by Douglas and Bremner (1971), Klein and Koths (1980), Bolton et al. (1985), Kizılkaya et al. (1998a, b), and Garcia et al. (2000), Qian et al. (2012) and Bi et al. (2019).

On the other hand, dehydrogenase activity is used when assessing total microbiological activity in soils. However, this enzyme activity is not generally associated with the total number of microorganisms. Dehydrogenase activity is largely affected by environmental factors such as soil moisture and temperature, and by soil properties such as organic matter (Carpenter et al., 1995; Lipson et al., 1999). Therefore, the activity of this enzyme yields its microbiological activity at the moment when the soil sample is taken. However, the highest dehydrogenase activity was 
obtained from the soil in which the highest urease enzyme activity was obtained, i.e. from the rhizosphere soil of the plant Euphorbia helioscopia L. (Euphorbiaceae (no.9) as $14.27 \mu \mathrm{g}$ TPF per $1 \mathrm{~g}$ dry soil ${ }^{-1}$. This rhizosphere soil had a high number of mycorrhizal spores (83 in $\left.10 \mathrm{~g} \mathrm{soil}^{-1}\right)$ and the highest number of bacteria $(26 \times$ $10^{5} \mathrm{kob} / \mathrm{ml}$ ). The distribution of dehydrogenase activity in the study area soils is shown in Table 4. The results obtained from dehydrogenase activity of this paper were close to Ross (1970), Bolton et al. (1985), Kizılkaya et al. (1998b, c), Garcia et al. (2000), Qian et al. (2012).

Catalase activity is a criterion used when assessing aerobic microorganisms in soils. Therefore, the catalase activity of soils indicates the desire of soil microorganisms to live in aerobic conditions. Catalase activity varies depending on the aeration condition of soils, $\mathrm{O}_{2}$ concentration in the soil air, and the number of microorganisms (Schinner et al., 1996; Smith and Read, 2008). The distribution of catalase activity of the common plants existing in the rhizosphere soils around the SAPBD is shown in Table 4.

It was found that the catalase activity of the common plants in the rhizosphere soils around the SAPBD ranged between $0.6-7 \mathrm{ml} \mathrm{O}_{2}$ per $5 \mathrm{~g}_{\text {dry soil }}{ }^{-1}$ and that the soil with the highest activity was that of the plant Euphorbia helioscopia L. (Euphorbiaceae) (no.9). It was also found that this soil had the highest organic matter content $(5.27 \%)$ and the lowest $\mathrm{CaCO}_{3}$ content (1.69\%). In the literature Kizilkaya et al. (1998b, c), Garcia et al. (2000), Abdel Latef and Chaoxing (2011) also found their results in this range. In addition, Samuel et al. (2008) reported in their study that catalase activity was higher in the $0-20 \mathrm{~cm}$ part of the soil, i.e. in its top layer where there are more oxygen and more organic matter. Hence, they suggested that alternation had positive effects on the enzyme activity compared to monoculture.

The values regarding the $\mathrm{CO}_{2}$ production of the soils sampled from the rhizosphere zones of the common plants around the SAPBD are shown in Table 4. Carbon dioxide production is used as an indicator of microbial activity in the soil. While heterotopicqualified microorganisms in the soil decompose the organic matter, they produce $\mathrm{CO}_{2}$. This process continuing in the soil is also referred to as soil respiration. Although all conditions (moisture, temperature, etc.) affecting the soil microorganisms affect the amount of $\mathrm{CO}_{2}$, soil organic matter is the main soil property affecting the $\mathrm{CO}_{2}$ production (Cheng, 1999). It was found that the $\mathrm{CO}_{2}$ production in the rhizosphere soils of the prevalent plants around the SAPBD ranged between 31.62-73.06 $\mathrm{mg} \mathrm{CO}_{2} 10 \mathrm{~g}$ dry soil $^{-1}$, and the soil with the highest $\mathrm{CO}_{2}$ production was again detected in the rhizosphere soil of the plant Euphorbia helioscopia L. (Euphorbiaceae) (no.3), which had the highest organic matter content $(5.27 \%)$ and the lowest lime content $(1.69 \%$ $\mathrm{CaCO}_{3}$ ). K1z1lkaya et al. (1998c) investigated the microbiological properties of the soils of the Harran Plain and found that $\mathrm{CO}_{2}$ production varied between 4,5-70,3 $\mathrm{mg} \mathrm{CO}$ per $100 \mathrm{~g} \mathrm{soil}^{-1}$, K1zılkaya et al. (1998b) found that $\mathrm{CO}_{2}$ production varied between 15.50 $68.50 \mathrm{mg} \mathrm{CO}_{2}$ per $100 \mathrm{~g} \mathrm{soil}^{-1}$ in the forestry soils of Samsun-Alaçam and Kohler et al. (2009), Wang et al. (2017), Papp et al. (2018) found similar results.

On the other hand, three different spore species (Glomus sp., Acaulospora sp. and Entrophospora sp.) belonging to A.M. fungi were identified in the rhizosphere zones of the 10 plants. In the present study, since the spores isolated from the root rhizosphere region were directly prepared as slides without performing trap culture, a very clear image could not be taken from the spores and methodologically the spores could be identified only based on genus. 
Table 4. The results of DUNCAN test applied to some biological parameters determined in the plants and soils belonging to the plants and sampled soils around SAPBD

\begin{tabular}{|c|c|c|c|c|c|c|c|c|c|c|c|c|c|c|c|c|}
\hline $\begin{array}{c}\text { Soil } \\
\text { no }\end{array}$ & Host & $\begin{array}{c}\text { Microbial } \\
\text { respiration } \\
\left(\mathrm{mg} \mathrm{CO}_{2} 10 \mathrm{~g}\right. \\
\left.\text { dry soil }^{-1}\right)\end{array}$ & $\begin{array}{c}\text { Dehidrogenase } \\
\text { enzyme activity } \\
\text { (mg TPF 10 g } \\
\left.\text { soil }^{-1}\right)\end{array}$ & $\begin{array}{c}\text { Catalase } \\
\text { enzyme } \\
\text { activity } \\
\left(\mathrm{mg} \mathrm{O}_{2} 5 \mathrm{~g}\right. \\
\left.\text { soil }^{-1}\right)\end{array}$ & $\begin{array}{c}\text { Urease } \\
\text { enzyme } \\
\text { activity } \\
(\mu \mathrm{g} \mathrm{Ng} \\
\left.\text { dry soil }^{-1}\right)\end{array}$ & $\begin{array}{c}\text { Root } \\
\text { length } \\
(\mathbf{m} / \mathbf{g} \\
\text { plant })\end{array}$ & 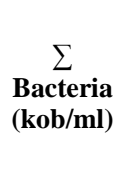 & $\underset{\substack{\text { Fungi } \\
\text { (kob/ml) }}}{\sum_{\text {mat }}}$ & $\begin{array}{c}\% \\
\text { Vesicle }\end{array}$ & $\begin{array}{c}\% \\
\text { Arbuscule }\end{array}$ & $\begin{array}{c}\% \\
\text { Hypha }\end{array}$ & $\begin{array}{c}\sum \text { spore } \\
\text { number } \\
\text { (number/10 } \\
\text { g dry soil) }\end{array}$ & $>38 \mu \mathrm{m}$ & $\begin{array}{l}>\mathbf{5 0} \\
\mu \mathrm{m}\end{array}$ & $\begin{array}{c}>100 \\
\mu \mathrm{m}\end{array}$ & $\begin{array}{c}>250 \\
\mu \mathrm{m}\end{array}$ \\
\hline 1 & $\begin{array}{l}\text { Onopordum } \\
\text { acanthium }\end{array}$ & $72.97 \mathrm{a}$ & 7.06cde & $4.87 \mathrm{c}$ & $29.08 \mathrm{~b}$ & 157.721 & $15.67 \mathrm{bc}$ & $10.00 \mathrm{~b}$ & $0.00 \mathrm{j}$ & $79.98 \mathrm{e}$ & $39.67 \mathrm{c}$ & $85.33 \mathrm{a}$ & $46.67 \mathrm{a}$ & $31.33 \mathrm{~b}$ & $6.33 \mathrm{e}$ & $1.00 \mathrm{bc}$ \\
\hline 2 & Festuca glauca & $71.02 \mathrm{a}$ & $6.50 \mathrm{cde}$ & $6.20 \mathrm{~b}$ & $18.32 \mathrm{cde}$ & $683.11 \mathrm{a}$ & $12.00 \mathrm{~cd}$ & $9.00 \mathrm{bc}$ & $29.67 \mathrm{~g}$ & $79.95 \mathrm{e}$ & $30.88 \mathrm{~d}$ & $53.33 \mathrm{c}$ & $26.00 \mathrm{c}$ & $10.67 \mathrm{e}$ & $16.33 \mathrm{c}$ & $0.33 \mathrm{~cd}$ \\
\hline 3 & $\begin{array}{c}\text { Euphorbia } \\
\text { helioscopiaL. }\end{array}$ & $73.06 \mathrm{a}$ & $9.18 b c$ & $7.00 \mathrm{a}$ & $17.91 \mathrm{cde}$ & $193.27 \mathrm{~g}$ & $8.00 \mathrm{ef}$ & 7.33bcd & $83.54 \mathrm{a}$ & $100.06 \mathrm{a}$ & $60.33 a$ & $87.67 \mathrm{a}$ & $20.00 \mathrm{~d}$ & $34.00 \mathrm{~b}$ & $32.00 \mathrm{a}$ & $1.67 \mathrm{~b}$ \\
\hline 4 & $\begin{array}{c}\text { Plantago } \\
\text { lanceolata } \mathrm{L} .\end{array}$ & $35.68 \mathrm{~d}$ & $7.37 \mathrm{~cd}$ & $3.60 \mathrm{e}$ & $27.24 b c$ & $190.01 \mathrm{~g}$ & $1.00 \mathrm{~g}$ & $3.67 \mathrm{~d}$ & $59.14 d$ & $92.36 \mathrm{~b}$ & $8.17 \mathrm{~g}$ & $26.00 \mathrm{e}$ & $6.00 \mathrm{~g}$ & $15.00 \mathrm{~d}$ & $4.67 \mathrm{e}$ & $0.33 \mathrm{~cd}$ \\
\hline 5 & $\begin{array}{c}\text { Salvia } \\
\text { officinalis }\end{array}$ & 63.87ab & $5.94 \mathrm{de}$ & $3.60 \mathrm{~d}$ & $14.91 \mathrm{de}$ & $212.89 \mathrm{f}$ & $18.00 \mathrm{~b}$ & $19.67 \mathrm{a}$ & $44.25 \mathrm{e}$ & $99.87 \mathrm{a}$ & $0.00 \mathrm{~h}$ & $64.33 b$ & $31.33 b$ & $27.67 \mathrm{c}$ & $5.00 \mathrm{e}$ & $0.33 \mathrm{~cd}$ \\
\hline 6 & $\begin{array}{c}\text { Mentha } \\
\text { pulegium } \mathrm{L} \text {. }\end{array}$ & $50.00 \mathrm{c}$ & $7.73 \mathrm{bcd}$ & $4.13 \mathrm{f}$ & $22.32 \mathrm{bcd}$ & $329.22 \mathrm{~d}$ & $9.67 \mathrm{de}$ & $9.67 \mathrm{~b}$ & $39.97 f$ & $79.97 \mathrm{e}$ & $10.00 \mathrm{~g}$ & $42.67 d$ & $23.67 \mathrm{c}$ & $0.67 \mathrm{~g}$ & $11.67 \mathrm{~d}$ & $6.67 \mathrm{a}$ \\
\hline 7 & $\begin{array}{l}\text { Verbascum } \\
\text { thapsus L. }\end{array}$ & $42.46 \mathrm{~cd}$ & $4.21 \mathrm{e}$ & $1.40 \mathrm{~g}$ & $8.71 \mathrm{e}$ & $260.62 \mathrm{e}$ & $4.67 \mathrm{fg}$ & $6.00 \mathrm{bcd}$ & $24.97 \mathrm{~h}$ & $83.81 \mathrm{~d}$ & $16.65 \mathrm{f}$ & $24.33 \mathrm{e}$ & $9.67 \mathrm{ef}$ & $10.00 \mathrm{e}$ & $4.67 \mathrm{e}$ & $0.00 \mathrm{~d}$ \\
\hline 8 & $\begin{array}{c}\text { Plantago } \\
\text { lanceolata } \mathrm{L} .\end{array}$ & $31.62 \mathrm{~d}$ & $10.73 b$ & $0.60 \mathrm{c}$ & $19.31 \mathrm{bcd}$ & $440.82 \mathrm{c}$ & 8.33def & $4.33 \mathrm{~d}$ & 20.281 & $79.34 \mathrm{e}$ & $19.99 \mathrm{e}$ & $26.00 \mathrm{e}$ & $7.67 \mathrm{fg}$ & $6.00 \mathrm{f}$ & $12.00 \mathrm{~d}$ & $0.33 \mathrm{~cd}$ \\
\hline 9 & $\begin{array}{c}\text { Euphorbia } \\
\text { helioscopia L. }\end{array}$ & $52.92 \mathrm{bc}$ & $14.27 \mathrm{a}$ & $4.60 \mathrm{~g}$ & $77.87 \mathrm{a}$ & $185.92 \mathrm{~h}$ & $26.00 \mathrm{a}$ & $5.00 \mathrm{~cd}$ & $69.14 \mathrm{c}$ & $100.51 \mathrm{a}$ & $42.50 \mathrm{~b}$ & $83.00 \mathrm{a}$ & $26.00 \mathrm{c}$ & $39.00 \mathrm{a}$ & $16.33 \mathrm{c}$ & $1.67 \mathrm{~b}$ \\
\hline 10 & $\begin{array}{c}\text { Crocus sativus } \\
\text { L. }\end{array}$ & $37.15 \mathrm{~d}$ & $14.25 \mathrm{a}$ & $0.60 \mathrm{~g}$ & $12.62 \mathrm{de}$ & $490.46 \mathrm{~b}$ & $18.33 b$ & $9.33 b c$ & $75.14 \mathrm{~b}$ & $87.44 \mathrm{c}$ & $37.80 \mathrm{c}$ & $47.33 \mathrm{~d}$ & $11.67 \mathrm{e}$ & $14.00 \mathrm{~d}$ & $21.67 \mathrm{~b}$ & $0.33 \mathrm{~cd}$ \\
\hline LSD & & 11.83 & 3.154 & 0.4542 & 10.49 & 4.095 & 3.672 & 4.388 & 1.689 & 1.462 & 2.149 & 4.933 & 2.764 & 2.853 & 2.053 & 0.8544 \\
\hline
\end{tabular}

$* \mathrm{P}<0.05, * * \mathrm{P}<0.01$ 
Table 5. The results of correlation test applied to some parameters determined belonging to the sampled plants and soils around SAPBD

\begin{tabular}{|c|c|c|c|c|c|c|c|c|c|c|c|c|c|c|c|}
\hline \multirow[b]{2}{*}{$\begin{array}{l}\text { Properties of soil } \\
\text { and plant }\end{array}$} & \multirow{2}{*}{$\begin{array}{c}\text { Microbial } \\
\text { respiration } \\
\left(\mathbf{m g ~ C O}_{2} 10 \mathrm{~g}\right. \\
\left.\text { dry soil }^{-1}\right)\end{array}$} & \multicolumn{4}{|c|}{ Mycorrhizal fungus spore } & \multirow[b]{2}{*}{$\begin{array}{l}\text { Total spor } \\
\text { (number/ } \\
10 \mathrm{~g} \text { soil) }\end{array}$} & \multirow[b]{2}{*}{$\begin{array}{c}\text { Rate of } \\
\text { vesicle (\%) }\end{array}$} & \multirow[b]{2}{*}{$\begin{array}{c}\text { Rate of } \\
\text { arbuscule } \\
(\%)\end{array}$} & \multirow[b]{2}{*}{$\begin{array}{c}\text { Rate of } \\
\text { hypha }(\%)\end{array}$} & \multirow[b]{2}{*}{$\begin{array}{l}\text { Root length } \\
\text { (m/g plant) }\end{array}$} & \multirow{2}{*}{ 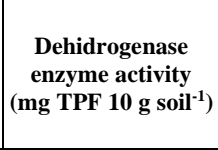 } & \multirow{2}{*}{$\begin{array}{c}\text { Catalase } \\
\text { enzyme } \\
\text { activity } \\
\left(\mathrm{mg} \mathrm{O}_{2} 5 \mathrm{~g}\right. \\
\left.\text { soil }^{-1}\right)\end{array}$} & \multirow{2}{*}{$\begin{array}{c}\text { Urease } \\
\text { enzyme } \\
\text { activity } \\
(\mu \mathrm{g} \mathrm{N} \mathrm{g} \mathrm{dry} \\
\left.\text { soil }^{-1}\right)\end{array}$} & \multirow{2}{*}{$\begin{array}{c}\sum_{\text {Fungi }} \\
\text { number } \\
\text { kob/ml }\end{array}$} & \multirow{2}{*}{$\begin{array}{c}\sum_{\text {Bacteria }} \\
\text { number } \\
\text { kob/ml }\end{array}$} \\
\hline & & $38 \mu \mathrm{m}$ & $50 \mu \mathrm{m}$ & $100 \mu \mathrm{m}$ & $250 \mu \mathrm{m}$ & & & & & & & & & & \\
\hline $\mathrm{pH}$ & 0.0063 & -0.1919 & -0.0770 & 0.0891 & $-0.6250 *$ & -0.1557 & $-0.4506^{*}$ & -0.1370 & 0.0199 & 0.2123 & $-0.4098^{*}$ & -0.2734 & $-0.5802 * *$ & 0.2091 & -0.2915 \\
\hline $\mathrm{EC} \mu \mathrm{S} / \mathrm{cm}$ & $0.5792^{*}$ & $0.3582 *$ & -0.0603 & 0.1028 & -0.1012 & 0.1780 & -0.1469 & -0.2461 & $0.6547 * *$ & $0.5870^{* *}$ & -0.2727 & $0.6157 * *$ & -0.1207 & 0.1660 & 0.0104 \\
\hline$\% \mathrm{CaCO}_{3}$ & $-0.5028 *$ & -0.3384 & -0.0338 & 0.1893 & -0.1163 & -0.1317 & 0.0752 & -0.0463 & 0.0080 & 0.2100 & $0.6653 * *$ & $-0.5285^{*}$ & $0.4146^{*}$ & -0.3476 & $0.3652^{*}$ \\
\hline$\%$ Clay & 0.3437 & 0.2015 & 0.1809 & 0.2017 & $-0.4388^{*}$ & 0.2312 & 0.2462 & 0.0118 & $0.6839^{* *}$ & $0.4829^{*}$ & 0.2872 & $0.3894 *$ & 0.0032 & 0.0003 & 0.1696 \\
\hline$\%$ Silt & $0.6732 * *$ & $0.4673 *$ & -0.0474 & -0.0910 & 0.0884 & 0.1875 & -0.2346 & -0.1972 & $0.3872^{*}$ & 0.2504 & $-0.5593^{*}$ & $0.7478^{* *}$ & -0.2332 & 0.2529 & -0.2224 \\
\hline \% Sand & $-0.6827 * * *$ & $-0.4683^{*}$ & -0.0163 & 0.0315 & 0.0568 & -0.2302 & 0.1371 & 0.1665 & $-0.5367 *$ & -0.3478 & $0.3982 *$ & $-0.7618^{* *}$ & 0.1920 & -0.2070 & 0.1443 \\
\hline$\%$ Org. Mat. & 0.4621 & 0.3398 & 0.2954 & 0.0457 & -0.2484 & 0.3218 & $0.4101 *$ & 0.0702 & $0.7505 * *$ & 0.3214 & 0.3383 & $0.6050^{* *}$ & 0.3280 & -0.1564 & 0.2989 \\
\hline$(\%) \mathrm{N}$ & $-0.5870^{*}$ & $0.4520 *$ & 0.1585 & $-0.5089 *$ & 0.0131 & 0.1334 & 0.2484 & 0.1411 & 0.3019 & -0.2547 & -0.1891 & $0.7979 * *$ & 0.0441 & -0.1469 & -0.3415 \\
\hline $\mathrm{P}_{2} \mathrm{O}_{5} \mathrm{mg} \mathrm{kg}^{-1}$ & $0.8144 * *$ & 0.3531 & 0.1715 & -0.0291 & -0.2090 & 0.2408 & $0.3915^{*}$ & 0.0979 & $0.6543^{* *}$ & 0.2856 & -0.0512 & $0.7792 * *$ & -0.0484 & 0.0490 & -0.0296 \\
\hline $\mathrm{K}_{2} \mathrm{O} \mathrm{mg} \mathrm{kg}^{-1}$ & $0.6619^{* *}$ & $0.4071^{*}$ & $0.3959^{*}$ & -0.0107 & -0.2271 & $0.3901^{*}$ & $0.4733^{*}$ & 0.3352 & $0.4226^{*}$ & -0.0812 & -0.1427 & $0.7594 * *$ & -0.1297 & 0.2332 & -0.0408 \\
\hline Ca mg kg-1 & $0.5275^{*}$ & 0.3452 & -0.0615 & -0.0732 & 0.1402 & 0.1288 & $-0.3891 *$ & -0.1457 & 0.0780 & 0.0495 & $-0.7482 * *$ & $0.4929^{*}$ & -0.3232 & $0.3613^{*}$ & -0.2633 \\
\hline $\mathrm{Mg} \mathrm{mg} \mathrm{kg}^{-1}$ & $0.5014^{*}$ & 0.2626 & -0.0861 & $-0.4297^{*}$ & 0.0449 & -0.0589 & 0.0226 & -0.0117 & 0.1182 & -0.1300 & $-0.6399^{* *}$ & $0.6665^{* *}$ & -0.3525 & 0.0658 & $-0.5589^{*}$ \\
\hline $\mathrm{Fe} \mathrm{mg} \mathrm{kg}^{-1}$ & $0.4812^{*}$ & $0.5361^{*}$ & 0.1864 & -0.3142 & 0.2288 & 0.2776 & 0.0400 & 0.0438 & 0.3174 & -0.1261 & $-0.3543^{*}$ & 0.8897 ** & 0.2467 & -0.0262 & -0.0851 \\
\hline $\mathrm{Cu} \mathrm{mg} \mathrm{kg}{ }^{-1}$ & $0.5496^{*}$ & $0.4268^{*}$ & 0.0568 & $-0.4523 *$ & -0.1493 & 0.0748 & -0.0134 & -0.1274 & $0.4113^{*}$ & -0.0208 & -0.2654 & $0.7271 * *$ & -0.1339 & -0.1286 & $-0.3949^{*}$ \\
\hline Mn mg kg-1 & -0.3006 & $-0.3727 *$ & -0.0993 & -0.3337 & -0.1560 & $-0.3696^{*}$ & 0.1700 & $0.4370^{*}$ & -0.3114 & -0.2319 & -0.1646 & 0.0522 & 0.0364 & -0.3094 & $-0.5200^{*}$ \\
\hline $\mathrm{Zn} \mathrm{mg} \mathrm{kg} \mathrm{g}^{-1}$ & $-0.3578^{*}$ & -0.3190 & -0.2971 & 0.0904 & -0.3342 & -0.3122 & 0.0162 & -0.3215 & 0.2753 & $0.5347^{*}$ & $0.4718^{*}$ & $-0.4061 *$ & -0.1287 & -0.2762 & 0.0004 \\
\hline Mic. Resp. & - & $0.8105^{* *}$ & $0.5016^{*}$ & 0.0660 & 0.0220 & $0.6969 * *$ & -0.0919 & -0.0247 & $0.4549 *$ & -0.1053 & -0.3261 & $0.7995 * *$ & 0.0732 & $0.3866^{*}$ & 0.2875 \\
\hline $38 \mu \mathrm{m}$ & $0.8105 * *$ & - & $0.5152 *$ & -0.0823 & 0.1973 & $0.7609 * *$ & -0.2163 & -0.1766 & $0.4878^{*}$ & -0.2418 & -0.0526 & $0.7047 * *$ & 0.2522 & 0.2735 & $0.3936^{*}$ \\
\hline $50 \mu \mathrm{m}$ & $0.5016^{*}$ & $0.5152 *$ & - & 0.2599 & 0.1192 & 0.1023 & 0.2406 & $0.6306 * *$ & 0.0880 & $-0.5841^{* * *}$ & 0.1868 & $0.4092 *$ & $0.5339 *$ & 0.2807 & $0.6091 * *$ \\
\hline $100 \mu \mathrm{m}$ & 0.0660 & -0.0823 & 0.2599 & - & 0.1192 & $0.4558 *$ & 0.1616 & 0.2963 & -0.1507 & 0.2704 & 0.2184 & -0.1664 & -0.0018 & $0.6772 * *$ & $0.6132 *$ \\
\hline $250 \mu \mathrm{m}$ & 0.0220 & 0.1973 & -0.2299 & 0.1192 & - & 0.1023 & -0.0412 & -0.1426 & $-0.3537 *$ & -0.0946 & -0.0006 & 0.1402 & 0.1328 & 0.2343 & 0.0987 \\
\hline Total Spor & $0.6969 * *$ & $0.7609 * *$ & $0.8557 * *$ & $0.4558^{*}$ & 0.1023 & - & 0.0688 & 0.3336 & 0.2091 & -0.3404 & 0.1455 & $0.5233 * *$ & $0.4169^{*}$ & $0.5425^{*}$ & $0.7404 *$ \\
\hline Rate of vesicle & -0.0919 & -0.2163 & 0.2406 & 0.1616 & -0.0412 & 0.0688 & - & $0.6447^{* *}$ & 0.0333 & -0.1170 & $0.5009^{* *}$ & 0.1557 & 0.2166 & -0.0896 & 0.1638 \\
\hline Rate of arbuscule & -0.0247 & -0.1766 & $0.6306 * *$ & 0.2963 & -0.1426 & 0.3336 & $0.6447^{* * *}$ & - & $-0.3784 *$ & $-0.5362 *$ & 0.1910 & 0.1531 & $0.3932 *$ & 0.1277 & 0.2239 \\
\hline Rate of hypha & $0.4549^{*}$ & $0.4878^{*}$ & 0.0880 & -0.1507 & $-0.3537 *$ & 0.2091 & 0.0333 & $-0.3784 *$ & - & $0.4911^{*}$ & 0.2321 & $0.4313^{*}$ & 0.0758 & -0.1847 & 0.2206 \\
\hline Root length & -0.1053 & -0.2418 & $-0.5841^{* *}$ & 0.2704 & -0.0946 & -0.3404 & -0.1170 & $-0.5362^{*}$ & $0.4911^{*}$ & - & 0.0988 & -0.1629 & -0.3274 & -0.0284 & -0.0091 \\
\hline Dehidrog. Enz. Act. & -0.3261 & -0.0526 & 0.1868 & 0.2184 & -0.0006 & 0.1455 & $0.5009^{*}$ & 0.1910 & 0.2321 & 0.0988 & - & -0.2014 & $0.4203 *$ & -0.2431 & $0.4963^{*}$ \\
\hline Catalase Enz. Act. & $0.7995 * *$ & $0.7047 * *$ & $0.4092 *$ & -0.1664 & 0.1402 & $0.5233 *$ & 0.1557 & 0.1531 & $0.4313^{*}$ & -0.1629 & -0.2014 & - & 0.2602 & 0.1196 & 0.0696 \\
\hline Urease Enz. Act. & 0.0732 & 0.2522 & $0.5339^{*}$ & -0.0018 & 0.1328 & $0.4169^{*}$ & 0.2166 & $0.3932^{*}$ & 0.0758 & -0.3274 & $0.4203^{*}$ & 0.2602 & - & -0.3006 & $0.5497 *$ \\
\hline$\sum$ Fungi numb. & $0.3866^{*}$ & 0.2735 & 0.2807 & $0.6772 * *$ & 0.2343 & $0.5425^{*}$ & -0.0896 & 0.1277 & -0.1847 & -0.0284 & -0.2431 & 0.1196 & -0.3006 & - & 0.3273 \\
\hline$\sum$ Bacteria numb. & 0.2875 & $0.3936^{*}$ & $0.6091^{* *}$ & $0.6132 * *$ & 0.0987 & $0.7404 * *$ & 0.1638 & 0.2239 & 0.2206 & -0.0091 & $0.4963 *$ & 0.0696 & $0.5497 *$ & 0.3273 & - \\
\hline
\end{tabular}




\section{Conclusions}

This is the first study that has attempted to describe the diversity and distribution of A.M. fungi in the mine area rhizosphere soils in Turkey. Mycorrhizal parameters (infection rate, spore count, and morphological identification) were not examined on a very large number of host plants. Only the host plants that are dominant in the sampling area and in the sampling season were collected. The plants that were sampled around mine areas are available in every season, i.e. they do not exhibit any change. The plant species that are prevalently existent around Seydişehir Aluminum Plant in the autumn period.

In conclusion, the findings of this study emphasize the need for an understanding of the ecology of A.M. fungi in various ecosystems and soils for the successful selection and introduction of A.M. fungal species and strains for particular environments. A.M. fungi spore population in the soil and spore colonization in the plant root may change depending on seasonal variation, soil properties, host plant variety and the mechanism of the host plant (He et al., 2002; Bohrer, 2004).

In the present study, significant correlations were found both among the microbial parameters in the soil and among certain properties of the soil in general. The presence of life forms in a soil and their activity are among the most important indicators of that soil's health and quality. As a matter of fact, although the present study was carried out on soil and plant samples around a mining area, the high number and activity of the microorganisms in the soil in the sampling period could be due to the prevalence of non-culture plants growing in the soil in the study area.

In addition, of the three spore genera mentioned above, Acaulospora in particular was found to be not only a spore genus dominant in the plant root rhizospheres, but also a spore genus with a high infection rate in the plant roots from which it was isolated.

This gives rise to the opinion that this spore genus contains spore species that are potentially important for the areas in the vicinity of bauxite deposits, and that the use of these spore species in the rehabilitation of the soils that possess similar conditions could yield useful results. For further studies, the symbiosis of plant Euphorbia helioscopia L. with arbuscular mycorrhiza and with other fungi should be considered in studies involving stressed environments. In addition, the authors suggest that the benefits of symbiosis for stressed environments should be investigated in detail.

\section{REFERENCES}

[1] Abdel Latef, A. A. H., Chaoxing, H. (2011): Effect of arbuscular mycorrhizal fungi on growth, mineral nutrition, antioxidant enzymes activity and fruit yield of tomato grown under salinity stres. - Scientia Horticulturae 127: 228-233.

[2] Aliasgharzadeh, N., Saleh Rastin, N., Towfighi, H., Alizadeh, A. (2001): Occurrence of arbuscular mycorrhizal fungi in saline soils of the Tabriz Plain of Iran in relation to some physical and chemical properties of soil. - Mycorrhiza 11: 119-122.

[3] Atabey, M. E. (1976): Mineralogy, chemistry and origin of the Mortas bauxite deposit, Seydisehir, Konya, Turkey. - Comite International pour I'REtude des Bauxites de l'Alumine et de l'Aluminium Travaux 13: 77-89 [Also published in Türkiye Jeoloji Kurumu Bülteni 19: 9-14 (in Turkish with English abstract)].

[4] Augé, R. M. (2001): Water relations, drought and vesicular-arbuscular mycorrhizal symbiosis. - Mycorrhiza. 11: 3-42. 
[5] Augé, R. M. (2004): Arbuscular mycorrhizae and soil/plant water relations. - Can. J. Soil Sci. 84: 373-381. DOI: 10.4141/S04-002.

[6] Bandick, A. K., Dick, R. P. (1999): Field management effects on soil enzyme activities. Soil Biol Biochem. 31: 1471-1479.

[7] Barea, J. M., Pozo, M. J., Azcón, R., Azcón-Aguilar, C. (2013): Microbial Interactions in the Rhizosphere. - In: Bruijn, F. de (ed.) Molecular Microbial Ecology of the Rhizosphere. Wiley-Blackwell, USA, pp. 29-44.

[8] Beck, T. H. (1971): Die Messung der Katalasenaktivität von Böden. - Z. Pflanzenernähr, Bodenkd. 130: 68-81.

[9] Bi, Y. L., Wang, J., Feng, Y. B., Yu, H. Y., Qin, Y. F., Yu, M. (2019): Effect of arbuscular mycorrhiza on root self-repairing action of Amorpha fruticosa L. in coal mining subsidence land in arid areas. - J. China Coal Soc. 8: 050.

[10] Biesboer, D. D, Amour, P. D., Wilson, S. R. Mahlberg, P. (1982): Sterols and triterpenols in latex and cultured tissues of Euphorbia pulcherrima. - Phytochemistry 21(5): 11151118.

[11] Biró B, Posta, K., Füzy, A., Kadar, I. (2005): Mycorrhizal functioning as part of the survival mechanisms of barley (Hordeum vulgare L.) at long-term heavy metal stress. Acta Biol Szeged 49: 65-67.

[12] Bohrer, K., Friese, C. F., Amon, J. P. (2004): Seasonal dynamics of arbuscular mycorrhizal fungi in differing wetland habitats. - Mycorrhiza 14: 329-337.

[13] Bolton, H. Jr., Elliot, L. F., Papendick, R. I., Bezdicek, D. F. (1985): Soil microbial biomass and selected enzyme activities: effect of fertilization and cropping practices. Soil Biol. Biochem. 17(3): 297-303.

[14] Bothe, H., Regvar, M., Turnau, K. (2010): Arbuscular Mycorrhiza, Heavy Metal, and Salt Tolerance. - In: Sherameti, I., Varma, A. (eds.) Soil Heavy Metals. Soil Biology. Vol. 19. Springer-Verlag, Berlin, pp. 87-111.

[15] Bouyoucos, G. J. (1995): A recalibration of the hydrometer method for making mechanical analysis of the soils. - Agronomy Journal 4(9): 434.

[16] Bremner, J. M. (1996): Nitrogen total. - In: Bartels, J. M., Bigham, J. M. (eds.) Methods of Soil Analysis. American Society of Agronomy, Madison, WI, pp. 1085-1121.

[17] Brundrett, M., Bougher, N., Dell, B., Grove, T., Malajczuk, N. (1996): Working with Mycorrhizas in Forestry and Agriculture. - ACIAR, Canberra.

[18] Camprubi, A., Calvet, C., Estaun, V. (1995): Growth enhancement of Citrus reshni after inoculation with Glomus intraradices and Trichoderma aureoviride and associated effects on microbial populations and enzyme activity in potting mixes. - Plant Soil. 173: 233-238.

[19] Carpenter-Boggs, L., Loynachan, T. E., Stahl, P. D. (1995): Spore germination of Gigaspora margarita stimulated by volatiles of soil-isolated actinomycetes. - Soil Biol Biochem. 27: 1445-1451.

[20] Cheng, W. (1999): Rhizosphere feedbacks in elevated $\mathrm{CO}_{2}$. - Tree Physiology 19: 313320.

[21] Cooke, J. C., Butlera, R. H., Madole, G. (1993): Some observations on the vertical distribution of vesicular arbuscular mycorrhizae in roots of salt marsh grasses growing in saturated soils. - Mycologia 85: 547-550.

[22] Cumming, J. R., Ning, J. (2003): Arbuscular mycorrhizal fungi enhance aluminium resistance of broomsedge (Andropogon virginicus L.). - J. Exp. Bot. 54(386): 1447-1459.

[23] Daei, G., Ardekani, M. R., Rejali, F., Teimuri, S., Miransari, M. (2009): Alleviation of salinity stress on wheat yield, yield components, and nutrient uptake using arbuscular mycorrhizal fungi under field conditions. - J. Plant Physiol. 166: 617-625. DOI: 10.1016/j.jplph.2008.09.013.

[24] Davis, P. H. (1965-1985): Flora of Turkey and the East Aegean Islands. - Edinburgh Univ. Press, Edinburg. 
[25] Dick, R. P. (1994): Soil Enzyme Activities as Indicators of Soil Quality. - In: Doran, J. W., Coleman, D. C., Bezdicek, D. F., Stewart, B. A. (eds.) Defining Soil Quality for a Sustainable Environment. SSSA Special Publication. Vol 35. Soil Science Society of America, Madison, Wl, pp. 107-124.

[26] Dietterich, L. H., Gonneau, C., Casper, B. B. (2017): Arbuscular mycorrhizal colonization has little consequence for plant heavy metal uptake in contaminated field soils. - Ecological Applications 27(6): 1862-1875.

[27] Douglas, L. A., Bremner, J. M. (1971): A rapid method of evaluating different compounds as inhibitors of urease in soils. - Soil Biol Biochem. 3: 309-315.

[28] Drews, G. (1983): Mikrobiologisches Praktikum für Naturwissen-schaftler. Fourth Ed. Springer Verlag, Berlin.

[29] Durrani, A. A., Rafiullah, M., Ikram, M. (1967): Euphorbia helioscopia Linn. - Pak J Sci \& Ind. Res. 10(3): 167-170.

[30] Eom, A. H., Hartnett, D. C., Wilson, G. W. T. (2000): Host plant species effects on arbuscular mycorrhizal fungal communities in tallgrass prairie. - Oecologia 122: 435444.

[31] Fernández, D. A., Roldán, A., Azcón, R., Caravaca, F., Bååth, E. (2012): Effects of water stress, organic amendment and mycorrhizal inoculation on soil microbial community structure and activity during the establishment of two heavy metal-tolerant native plant species. - Microb Ecol. 63(4): 794-803. DOI: 10.1007/s00248-011-9972-y.

[32] Finlay, R. (2008): Ecological aspects of mycorrhizal symbiosis: with special emphasis on the functional diversity of interactions involving the extraradical mycelium. - J Exp Bot. 59: 11151126.

[33] Garcia, C., Hernandez, T., Roldan, A., Albaladejo, J., Castillo, V. (2000): Organic amendment and mycorrhizal inoculation as a practice in afforestation of soils with Pinus halepensis Miller: effect on their microbial activity. - Soil Biology and Biochemistry 32(8-9)1173-1181.

[34] Garg, N., Kaur, H. (2013): Response of antioxidant enzymes, phytochelatins and glutathione production towards $\mathrm{Cd}$ and $\mathrm{Zn}$ Stresses in Cajanus cajan (L.) Mill sp genotypes colonized by arbuscular mycorrhizal fungi. - J Agron Crop Sci. 199: 118-133.

[35] Gerdeman, J. W., Nicolson, T. H. (1963): Spores of mychorriza endogene species. Extracted from soil by wet sieving and decanting. - Trans Brit Mycol Soc. 46: 235-244.

[36] Giovanneti, M., Mosse, B. (1980): An evaluation of techniques for measuring vesicular arbuscular mycorrhizal infection in roots. - New Phytol. 84: 489-500. http://dx.doi.org/10.1111/j.1469-8137.1980.tb04556.x.

[37] He, X., Mouratov, S., Steinberger, Y. (2002): Temporal and spatial dynamics of vesicular-arbuscular mycorrhizal fungi under the canopy of Zygophyllum dumosum Boiss. in the Negev Desert. - J. Arid Environ. 52: 379-387.

[38] Hizalan, E., Ünal, H. (1965): Soil Chemical Analysis. - University of Ankara Agriculture Faculty Publics, Ankara (in Turkish).

[39] Hoffmann, G. G., Teicher., K. (1961): Ein kolorimetrisches Verfahren zur Bestimmung der Urease Aktivität in Böden. - Z. Pflanzenernähr. Düng, Bodenk. 91: 55-63. (in German with English abstract).

[40] Huang, Y. Z., Zhong, M., Wu, W., Sui, L. H., Zhang, C., Hao, X. W. (2014): Effects of Arbuscular mycorrhizal fungi isolated from white clovers (Trifolium repens L.) on soil bacteria and fungi. - Chemistry and Ecology 30(2): 118-132.

[41] Huang, Z., Zou, Z. R., He, C. X., He, Z. Q., Zhang, Z. B., Li, J. M. (2011): Physiological and photosynthetic responses of melon (Cucumis melo L.) seedlings to three Glomus species under water deficit. - Plant Soil. 339: 391-399.

[42] INVAM (2004): Identification of AMF to genus level. - http://invam.caf.wvu.edu/.

[43] Isermeyer, H. (1952): Estimation of Soil Respiration in Closed Jars. - In: Alef, K., Nannipieri, P. (eds.) Method in Applied Soil Microbiology and Biochemistry. Academic Press, London, pp. 214-216. 
[44] Jackson, M. L. (1958): Soil Chemical Analysis. - Prentice-Hall, Inc., Englewood Cliffs, NJ, pp. 1-498.

[45] Janardhanan, K. K., Abdul-Khaling Naushin, F., Ramaswamy, K. (1994): Vesicular arbuscular mycorrhiza in an alkaline user land ecosystem. - Current Science 67: 465-469.

[46] Kızılkaya, R., Arcak, S., Horuz, A., Karaca, A. (1998a): Çeltik tarımı yapılan topraklarda enzim aktiviteleri ile toprak özellikleri arasındaki ilişkiler. - Pamukkale Üniversitesi Mühendislik Bilimleri Dergisi 4(3): 797-804. (in Turkish with English abstract).

[47] Kızılkaya, R., Sürücü, A., Arcak, S. (1998b): Samsun, Alaçam orman topraklarının bazı biyolojik ve kimyasal özellikleri. - XIV. Ulusal Biyoloji Kongresi. 7-10 Eylül. Samsun. Cilt I., pp. 240-254 (in Turkish with English abstract).

[48] Kızılkaya, R., Kızılgöz, İ., Arcak, S., Kaptan, H., Rakıcıŏlu, S. (1998c): Microbiological properties of soils of Harran Plain. - M. Şefik Yeşilsoy International Symposium on Arid Region Soil, 21-24 September, Menemen-İzmir, Turkey, pp. 569-574.

[49] Kieliszewska-Rokicka, B. (2001): Soil Enzymes and Their Importance in Soil Microbial Activity Estimation. - In: Dahm, H., Pokojska-Burdziej, A. (eds.) Drobnoustroje środowiska glebowego. Aspekty fizjologiczne, biochemiczne, genetyczne. Wydawnictwo Adam Marszałek, Toruń, pp. 37-47 (in Polish).

[50] Klauberg-Filho, O., Siqueira, J. O., Moreira, F. M. S. (2002): Fungos micorrízicos arbusculares em solos de área poluída com metais pesados. - R Bras Ci Solo 26: 125-134.

[51] Klein, T. M., Koths, J. S. (1980): Urease, protease and acid phosphatase in soil continuously cropped to corn by conventional or no-tillage methods. - Soil Biol. Biochem. 12(3): 293-294.

[52] Kohler, J., Caravaca, F., Mar, M., Alguacil, A. R. (2009): Elevated $\mathrm{CO}_{2}$ increases the effect of an arbuscular mycorrhizal fungus and a plant-growth-promoting rhizobacterium on structural stability of a semiarid agricultural soil under drought conditions. - Soil Biology and Biochemistry 41(8): 1710-1716.

[53] Kumar, A., Raghuwanshi, R., Upadhyay, R. S. (2003): Vesicular arbuscular mycorrhizal association in naturally revegetated coal mine spoil. - Tropical Ecology 44(2): 253-256.

[54] Li, H. Y., Li, D. W., He, C. M., Zhou, Z. P., Mei, T., Xu, H. M. (2012): Diversity and heavy metal tolerance of endophytic fungi from six dominant plant species in a $\mathrm{Pb}-\mathrm{Zn}$ mine wasteland in China. - Fungal Ecol 5(3): 309-315.

[55] Lindsay, W. L., Norvell, W. A. (1978): Development of a DTPA soil test for zinc, iron, manganese and copper. - Soil Sci Soc Am J 42: 421-428.

[56] Lipson, D. A., Schadt, C. W., Schmidt, S. K., Monson, R. K. (1999): Ectomycorrhizal transfer of amino acid-nitrogen to the alpine sedge Kobresia myosuroides. - New Phytol. 142: 163-167.

[57] Ma, Y., Oliveira, R. S., Freitas, H., Zhang, C. (2016): Biochemical and molecular mechanisms of plant-microbe-metal interactions: relevance for phytoremediation. - Front Plant Sci 7: 918. DOI: 10.3389/fpls.2016.00918.

[58] Madureira, A. M., Duarte, M. T., Piedade, M. F. M., Ascenso, J. R., Ferreira, M. J. U. (2004): Isoprenoid compounds from Euphorbia portlandica X-ray structure of lupeportlandol, a new lupane triterpene. - J. Braz. Chem. Soc. 15(5): 742-747.

[59] Maynard, D. S., Covey, K. R., Crowther, T. W., Sokol, N. W., Morrison, E. W., Frey, S. D., van Diepen, L. T. A., Bradford, M. A. (2018): Species associations overwhelm abiotic conditions to dictate the structure and function of wood-decay fungal communities. Ecology (Ecological Society of America) 99(4): 801-811.

[60] Meharg, A. A., Cairney, J. W. G. (2000): Co-evolution of mycorrhizal symbionts and their hosts to metal-contaminated environments. - Adv. Ecol. Res. 30: 69-112.

[61] Melloni, R., Siqueira, J. O., Moreira, F. M. S. (2003): Fungos micorrízicos arbusculares em solos de área de mineração de bauxita em reabilitação. - Pesq Agropec Bras 38: 267276.

[62] Meyer, J. B., Song-Wilson, Y., Foetzki, A., Luginbuhl, C., Winzeler, M., Kneubuhler, Y., Matasci, C., Mascher-Frutschi, F., Kalinina, O., Boller, T., Keel, C., Maurhofer, M. 
(2013): Does wheat genetically modified for disease resistance affect root colonizing pseudomonads and arbuscular mycorrhizal fungi? - PLoS One 8: e53825: 1-12.

[63] Minitab (1997): MINITAB Reference Manual. - Sowers, Lebanon, Pennsylvania.

[64] Nadgórska-Socha, A., Łukasik, I., Ciepał, R., Pomierny, S. (2006): The activity of selected enzymes in soil loaded with varied heavy metals level. - Acta Agrophysica 8(3): 713-725.

[65] Nuccio, E. E., Hodge, A., Pett-Ridge, J., Herman, D. J., Weber, P. K., Firestone, M. K. (2013): An arbuscular mycorrhizal fungus significantly modifies the soil bacterial community and nitrogen cycling during litter decomposition. - Environ Microbiol. 15: 1870-1881.

[66] Olsen, S. R., Cole, C. V., Watanabe, F. S., Dean, L. A. (1954): Estimation of Available Phosphorus in Soils by Extraction with Sodium Bicarbonate. - USDA Circular 939, US Government Printing Office, Washington, pp. 1-19.

[67] Öksüz, S., Gürek, F., Gil, R. R., Pengsuparp, T., Pezzuto, J. M., Cordell, G. A. (1995): Four diterpene esters from Euphorbia myrsinites. - Phytochemistry 38(6): 1457-1462.

[68] Öztürk, H., Hein, J. R., Hanilci, N. (2002): Genesis of the Dogan-kuzu and Mortas bauxite deposits, Taurides, Turkey: separation of $\mathrm{Al}, \mathrm{Fe}$, and $\mathrm{Mn}$ and implications for passive margin metallogeny. - Economic Geology 97: 1063-1077.

[69] Papp, M., Fóti, S., Nagy, Z., Pintér, K., Posta, K., Fekete, S., Csintalan, Z., Balogh, J. (2018): Rhizospheric, mycorrhizal and heterotrophic respiration in dry grasslands. European Journal of Soil Biology 85: 43-52.

[70] Phillips, J. M., Hayman, D. S. (1970): Improved procedures for clearing roots and staining parasitic and vesicular arbuscular mycorrhizal fungi for rapid assessment of infection. - Trans Br Mycol Soc. 55: 158-161.

[71] Qian, K., Wang, L., Yin, N. (2012): Effects of AMF on soil enzyme activity and carbon sequestration capacity in reclaimed mine soil. - International Journal of Mining Science and Technology 22(4): 553-557.

[72] Richards, L. A. (1954): Diagnosis and Improvements Salina and Alkali Soils. - U.S. Dep. Agr. Handbook 60, Stroudsburg.

[73] Ross, D. J. (1970): Effects of storage on dehydrogenase activities of soils. - Soil Biol. Biochem. 2: 55-61.

[74] Sahai, R., Rastogi, R. P., Jakupovic, J., Bohlmann, F. (1981): A diterpene from Euphorbia maddeni. - Phytochemistry 20(7): 1665-1667.

[75] Samuel, A. D., Domuta, C., Ciobanu, C., Şandor, M. (2008): Field management effects on soil enzyme activities. - Romanian Agricultural Research 25: 61-68.

[76] Schinner, F., Öhlinger, R., Kandeler, E., Margesin, R. (1996): Methods in Soil Biology. Springer Verlag, Berlin, pp. 1-426.

[77] Shaker-Koohi, S. (2014): Role of arbuscular mycorrhizal (AM) fungi in phytoremediation of soils contaminated: a review. - IJABBR 2(5): 1854-1864.

[78] Shetty, K. G., Banks, M. K., Hetrick, B. A. D., Schwab, A. P. (1994a): Biological characterization of a southeast Kansas mining site. - Water Air Soil Pollut. 78: 169-177.

[79] Shetty, K. G., Hetrick, B. A. D., Figge, D. A. H., Schwab, A. P. (1994b): Effects of mycorrhizae and other soil microbes on revegetation of heavy metal contaminated mine spoil. - Environ. Pollut. 86: 181-188.

[80] Shi, Z. Y., Zhang, L. Y., Li, X. L., Feng, G., Tian, C. Y., Christie, P. (2007): Diversity of arbuscular mycorrhizal fungi associated with desert ephemerals in plant communities of Junggar Basin, northwest China. - Applied Soil Ecology 35(1): 10-20.

[81] Silva, G. A., Trufem, S. F. B., Saggin-Júnior, O. J. (2005): Arbuscular mycorrhizal fungi in a semiarid copper mining area in Brazil. - Mycorrhiza 15: 47-53.

[82] Singh, J. S., Abhilash, P. C., Singh, H. B., Singh, R. P., Singh, D. P. (2011b): Genetically engineered bacteria: an emerging tool for environmental remediation and future research perspectives. - Gene 480(1): 1-9. 
[83] Smith, S. E., Read, D. J. (2008): Mycorrhizal Symbiosis. 3rd Ed. - Academic Press, London.

[84] Smith, S. E., Jakobsen, I., Gronlund, M., Simth, F. A. (2011): Roles of arbuscular mycorrhizas in plant phosphorus nutrition: interactions between pathways of phosphorus uptake in arbuscular mycorrhizal roots have important implications for understanding and manipulating plant phosphorus acquisition. - Plant Physiol. 156: 1050-1057.

[85] Speir, T. W. (1977): Studies on climosequence of soils in tussock grasslands. II. Urease, phosphatase and sulfatase activities of top soils and their relationships with other properties including plant available sulfur. - N. Z. J. Sci. 20: 159-166.

[86] Taheri, W. I., Bever, J. D. (2010): Adaptation of plants and arbuscular mycorrhizal fungi to coal tailings in Indiana. - Appl. Soil Ecol. 45: 138-143.

[87] Teresa, J. D. P., Urones, J. G., Marcos, I. S., Basabe, P., Cuadrado, M. J. S., Moro, R. F. (1987): Triterpenes from Euphorbia broteri. - Phytochem. 26(6): 1767-1776.

[88] Thalmann, A. (1968): Zur Methodik der Bestimmung der Dehydrogenase Aktivität im Boden mittels Triphenyltetrazoliumchlorid. - Landw. Forsch. 21: 249-259.

[89] Thomas, G. W. (1982): Exchangeable Cations. - In: Page, D. L., (ed.) Methods of Soil Analysis. Part II. Chemical and Microbiological Properties. 2nd Ed. American Society of Agronomy, Madison, WI, pp. 159-165.

[90] Tian, Y. H., Lei, Y. B., Zheng, Y. L., Cai, Z. Q. (2013): Synergistic effect of colonization with arbuscular mycorrhizal fungi improves growth and drought tolerance of Plukenetia volubilis seedlings. - Acta Physiol Plant. 35: 687-696.

[91] Utobo, E. B., Tewari, L. (2014): Soil enzymes as bioindicators of soil ecosystem status. Applied Ecology and Environmental Research 13(1): 147-169.

[92] Uzair, M., Loothar, B. A., Choudhary, B. A. (2009): Biological screening of Euphorbia helioscopia L.. - Pak J Pharm Sci. 22(2): 184-186.

[93] Wang, F. Y., Liu, R. J., Lin, X. G., Zhou, J. M. (2004): Arbuscular mycorrhizal status of wild plants in saline-alkaline soils of the Yellow River Delta. - Mycorrhiza 14: 133-137.

[94] Wang, H., Liu, S., Wang, J., Li, D., Shi, Z., Liu, Y., Xu, J., Hong, P., Yu, H., Zhao, Z., Ming, A., Lu, L., Cai, D. (2017): Contrasting responses of heterotrophic and rootdependent respiration to soil warming in a subtropical plantation. - Agricultural and Forest Meteorology 247: 221-228.

[95] Wang, J., Huang, Y., Jiang, X. Y. (2011): Influence of ectomycorrhizal fungi on absorption and balance of essential elements of Pinus tabulaeformis seedlings in saline soil. - Pedosphere 21: 400-406.

[96] Wehner, J., Antunes, P. M., Powell, J. R., Mazukatow, J., Rillig, M. C. (2010): Plant pathogen protection by arbuscular mycorrhizas: a role for fungal diversity? Pedobiologia 53: 197-201.

[97] Yamamura, S., Shizuri, Y., Koemura, S. (1989): Diterpenes from Euphorbia helioscopia. - Phytochemistry 28(12): 3421-3436.

[98] Zhang, W., Guo, Y. W. (2006): Chemical studies on the constituents of the Chinese medicinal herb Euphorbia helioscopia L. - Chem Pharm Bull. 54(7): 1037-1039.

[99] Zarei, M., Hempel, S., Wubet, T. (2010): Molecular diversity of arbuscular mycorrhizal fungi in relation to soil chemical properties and heavy metal contamination. - Environ Pollut. 158(8): 2757-2765.

[100] Zubek, S., Nobis, M., Blaszkowski, J., Mleczko, P., Nowak, A. (2011): Fungal root endophyte associations of plants endemic to the Pamir Alay Mountains of Central Asia. Symbiosis 54(3): 139-149.

[101] Zubek, S., Błaszkowski, J., Seidler-Łożykowska, K., Bąba, W., Mleczko, P. (2013): Arbuscular mycorrhizal fungi abundance, species richness and composition under the monocultures of five medicinal plants. - Acta Sci Pol-Hortoru. 12: 127-141. 